\title{
Giulio Mongeri'nin Erken Cumhuriyet Dönemi Yapısı Eskişehir Ziraat Bankası'nın Kültürel Miras Yönetimi Kapsamında İncelenmesi
}

\section{Analyzing of Giuilo Mongeri's Early Republic Period Building Eskişehir Ziraat Bank in Scope of Cultural Heritage Management}

\section{Şule Pfeiffer-Taş ${ }^{\star} \mathbb{0}$, Rabia Temel $^{\star \star}$}

Öz

Eskişehir Ziraat Bankası Binası, Giulio Mongeri'nin (1873-1951) Erken Cumhuriyet Dönemi'nde Anadolu'da tasarladığı şubeler arasındadır. Kent kimliğinin simge yapılarından olup Birinci Ulusal Mimarlık olarak adlandırılan dönemin özelliklerini taşımaktadır.

Ziraat Bankası'nın (kuruluş 1888), Eskişehir'de bir şube açmak için arazi tahsisi talebi 1906-1907'deki yazışmalardan izlenebilmektedir. Binanın yapımına 1928 yılında başlanabilmiş, açılışı Cumhuriyet'in kuruluşunun yedinci yıl dönümünde 29 Ekim 1930'da gerçekleşmiştir. 1978 yılında bu bina yıkılmak istenmiş, 1979 yılında, 1930 yılı öncesine ait Cumhuriyet Dönemi Yapısı olması nedeniyle Korunması Gerekli Taşınmaz Kültür Varlığı olarak tescillenmiştir. 2005’te Koruma Grubu I (bir) kategorisine alınmıştır. Zaman içinde çeşitli müdahaleler geçirmiştir ancak öncesinde restitüsyon araştırması yapılmaması nedeniyle değişikliklerin izlenmesi zorlaşmaktadır.

Çalışma, arşivlerden derlenen belgeler, çizimler, eski fotoğraflar vb. ışığında yapıdaki değişimlerin izini sürerek ve diğer yapılarla karşılaştırarak özgün mimari ve sanatsal öğeleri ortaya koymayı amaçlamaktadır. Mongeri'nin Ziraat Bankası Eskişehir Şube Binası'nda, akımın özelliklerini yansıttığı tasarım unsurları ve yapının dönem içindeki değeri irdelenmektedir. Bulgular, Mongeri'nin eserinin akımın özelliklerini cephe düzenlemesinde, giriş ve müşteri holü iç mekân tasarımında, Bursa kemeri, mukarnas, hatayi, rumi vb. Selçuklu-Osmanlı unsurlarını da kullanarak günümüze kadar yansıttığını göstermektedir. Giriş kapısındaki değişiklik, özgün mobilyaların günümüze ulaşamaması, iç mekânda kapı yapılması, teknoloji bağlantılı değişiklikler gibi nedenlerle bütüncül değeri azalsa da, yapı Birinci Ulusal Mimarlık akımı özelliklerini korumaktadır.

\section{Anahtar Kelimeler}

Birinci Ulusal Mimarlık Akımı, Ziraat Bankası, Eskişehir, Giulio Mongeri, Kültürel Miras Yönetimi

\begin{abstract}
Eskişehir Ziraat Bank Building is one of the branch buildings which was designed by Giulio Mongeri (1873-1951) in Anatolia during the Early Republican Period. The building's design has features of the First National Architectural Movement and it is one of the symbol buildings of urban identity.
\end{abstract}

* Sorumlu Yazar: Şule Pfeiffer-Taş (Prof. Dr.), Atılım Üniversitesi, Güzel Sanatlar, Tasarım ve Mimarlık Fakültesi, Güzel Sanatlar Ortak Dersler Bölümü; Türkiye Tarih Araştırmaları Uygulama ve Araştirma Merkezi, Ankara, Türkiye.

E-posta: sule.pfeiffer@atilim.edu.tr; ORCID: 0000-0002-2262-483X

** Rabia Temel (Arş. Gör.), Atılım Üniversitesi, Güzel Sanatlar, Tasarım ve Mimarlık Fakültesi, Güzel Sanatlar Ortak Dersler Bölümü; Sosyal Bilimler Enstitüsü, İç Mimarlık ve Çevre Tasarımı Yüksek Lisans Öğrencisi, Ankara, Türkiye. E-posta: rabia.temel@atilim.edu.tr; ORCID: 0000-0002-5525-6770

Attf: Pfeiffer-Taş, Şule ve Temel, Rabia. “Giulio Mongeri'nin Erken Cumhuriyet Dönemi Yapısı Eskişehir Ziraat Bankası'nın Kültürel Miras Yönetimi Kapsamında Incelenmesi." Art-Sanat, 14(2020): 349-384. https://doi.org/10.26650/artsanat.2020.14.0014 
According to correspondence from 1906 and 1907, Ziraat Bank (established in 1888) requested land for the new branch building in Eskişehir. Construction started in 1928, and the building was opened on the seventh anniversary of the Republic's establishment on 29th October 1930. In 1978, the company requested to demolish the building. In 1979 it was registered as Immovable Cultural Property to be Protected since it belongs to the pre-1930 Republic Era. In 2005, it was designated as Protection Category I (one). The building underwent various interventions during the time. However, it is hard to follow these because of the lack of any restitution project.

The study aims to reveal the original architectural and artistic elements of the building by tracing the changes in the structure and comparing it with other buildings, according to documents, reports, drawings, and photographs received from archives. In this study we evaluate the elements of Mongeri's Eskişehir Ziraat Bank Building's design that reflect the movement's features and we also consider the place it held in its era.

The results of our study show that Mongeri used the features of this movement in the arrangements of the facades, and also in the entrance and customer hall using Ottoman elements such as Bursa arches, muqarnas, hatayi, and so on, and all these elements can be seen today. Although the building's holistic value has been reduced because of changes in the entrance door as well as the non-existence of original furniture, the addition of a new interior door, and modifications related to technological improvements, the building still has the characteristics of the First National Architecture Movement.

\section{Keywords}

First National Architecture Movement, Ziraat Bank, Eskişehir, Giulio Mongeri, Cultural Heritage Management

\section{Extended Summarv}

Eskişehir Ziraat Bank Building (1928-1930) is one of the branch buildings which was designed by Giulio Mongeri (1873-1951) in Anatolia for Ziraat Bank during the Early Republican Period. The building's design has features of the later as First National Architectural called Movement and it is one of the symbol buildings of urban identity. The building began to be constructed in 1928, and the opening ceremony took place on 29 October 1930 during the celebration of the seventh anniversary of the Republic. In 1978, the company planned to demolish the building. In 1979 it was registered as an Immovable Cultural Property to be Protected since it belongs to the pre-1930 Republic Era. In 2005, it was designated as Protection Category I (one).

Over time, the building underwent various interventions. However, it is hard to follow these because of the lack of any restitution project records. During our research on the building's interior, it was possible to investigate only the customer hall on the ground floor of the building, due to security measures. The study aims to reveal the original architectural and artistic elements of the building by tracing the changes in the structure and comparing it with other buildings. Our examination of Ziraat Bank Eskişehir Branch Building's historical process was completed using documents, photographs, and reports from Eskişehir Region Directorate of Cultural and Natural Heritage Preservation Board, and Municipality of Tepebaşı, Eskişehir. While the plan was analyzed, we used records from before alteration current project and from the 2013 alteration project obtained from T.C. Ziraat Bank Construction Management Department's Archive. 
The First National Architectural movement took place between ca. 1908 and 1930 very higly. The forerunners of this movement were Architect Kemaleddin, Vedat (Tek), Arif Hikmet (Koyunoğlu), and Giulio Mongeri. This movement was initiated to create an architectural identity in which the Seljuk and Ottoman styles were revived in the last period of the empire with new materials and techniques. It ended around the mid-1930s because it became impossible to reflect the young Republic's modern characteristics and new spatial needs. Giulio Mongeri is one of the Levantine architects who had a significant role in the First Nationalist Style. Giulio Mongeri was born in Istanbul and completed his education at the Brera Fine Arts Academy in Milan, Italy. After he returned to Istanbul, he started his own business working on free architectural works from his office. Later he became one of the teachers of the Academy of Fine Arts (Sanayi-i Nefise Mektebi) and worked there at intervals from 1909 to 1928 . He carried out many projects mostly in Istanbul and Ankara, such as Karaköy Palace (1920), Maçka Palace (1922), Osmanlı Bank (1926), Iş Bank (1929), Ziraat Bank (1929), the Headquarter's Building of Tekel (1928), and elsewhere.

Since he was an official architect of Ziraat Bank, he built many branch buildings in several cities such as Izmir, Aydın, Kütahya, Manisa, Adana etc.. Mongeri made a significant contribution to the history of Turkish architecture with several examples in three different styles: "Western-influenced Eclectic Style," "First National Architectural Movement," and "Modern Architecture." One of the First National Architectural style buildings which express the Seljuk and Ottoman architectural elements was Ziraat Bank Eskişehir Branch Building (1928-1930). The building's facades have classical elements of the style, such as reliefs, the shape of windows, plasters, details emphasizing the entrance, etc. The facades were not organized symmetrically because of the built-up area, except the entrance facade. The front of the building that faced the streets had more ornaments and reliefs than the rear of the building. Facades were partitioned vertically and horizontally with moldings and plasters. The form of the windows varied across floors. Vertical elements created a rhythm on the facades and thus the building is cited as an example of the effects from Renaissance style during the First National Architectural Movement. Ornaments which were placed above the windows of the first floor matched the Bursa typed arches in the customer hall. The arches which reflect the 14th and 15th Century Ottoman Architecture were assembled with muqarnas headed pillars as one of the most determinative elements of Seljuk and Ottoman Architecture. Reliefs under the arches, motives on the pillars, and the above-mentioned elements are the representatives of the movement. Vertically placed ornaments from both exterior and interior created unity in the design. The building has three floors: the basement functioned as storage, the ground floor was available for banking services, and the first floor was planned as lodging for employees of the bank. Today these lodging areas have been transformed into offices. 
The changes and their effects on Ziraat Bank, as one of the symbol buildings of urban memory, are evaluated in the concluding section of this article. Except the main entrance door and the label of the bank had been changed repeatedly and some of the reliefs are not preserved, also some other few changes, the building facades still have some of the original elements. Maintenance applications conserved the roof. The building's historical area totally changed over time and thus, it became hard to recognize the historic building in its modern surroundings. In the interior, the furniture, heating systems, and lighting systems have changed due to technological developments. These changes were made with sensitivity so as not to harm the unique elements of the building as much as possible. The columns and arches have been particularly well preserved.

The results of our research show that Mongeri used the features of First National Architectural movement in the arrangement of the facades, in the entrance hall, and in the customer hall using Bursa arches, muqarnas, hatayi, and so on, and all these elements are still intact today. Although the building's holistic value has been reduced because of changes in the entrance door, the non-existence of original furniture, the addition of a new interior door, and modifications related to technological improvements, the building still has the characteristics of the First National Architecture Movement. 


\section{Giriş}

Cumhuriyet' in ilk yıllarında başta Ankara olmak üzere Anadolu kentlerinde genellikle kamu yapıları Birinci Ulusal Mimarlık akımı özelliklerinde tasarlanmıştır. Eskişehir'de bu akım özelliklerinde inşa edilen kamu yapılarından birisi de Mimar Giulio Mongeri’nin tasarladığı Eskişehir Ziraat Bankası Şube Binası'dır (1928-1930). Yapı, ilk işlevini sürdürmektedir. Zaman içinde yapıda teknolojik gelişimler ve kullanımdan kaynaklanan değişiklikler ve müdahaleler olmuştur. Ancak, müdahaleler öncesi yapıya ait bir restitüsyon araştırması yapılmamış olması yapının özgün tasarım özelliklerinin belirlenmesini zorlaştırmaktadır. Yapıldığı döneme ait verilerin eksikliği ve yapıdan gelen izlerin müdahaleler ile kaybolması araştırmaları sınırlandırmaktadır.

$\mathrm{Bu}$ araştırmanın konusu, Eskişehir 1. Derece Korunması Gereken Taşınmaz Kültür Varlığı olarak tescillenen Ziraat Bankası Eskişehir Şube Binası’ nın en azından günümüze ulaşmış hâliyle Birinci Ulusal Mimarlık Akımı özelliklerini yansıtan unsurlarının ortaya konmasıdır.

Makalede, önce Birinci Ulusal Mimarlık Akımı, tanımlaması ve tasarım ilkeleri ile ilgili kuramsal bilgiler aktarılmıştır. İtalyan asıllı bir mimar olan Giulio Mongeri’ nin hayatı, eserleri ve üslubundaki değişiklikler bu kapsamda ele alınmıştır. Eskişehir Ziraat Bankası Binası'nın yerinin tahsisi, tescil ve korunma durumu, geçirdiği onarımlar vb. ile ilgili bilgiler, Başbakanlık Osmanlı Arşivi, Ziraat Bankası'nın kurumsal arşivi, koruma kurulları vb. sorumlu kurumlardan alınan belge, rapor, çizim ve fotoğraflar değerlendirilmiştir. Yerinde incelemelerde, cephe ve güvenlik nedeniyle müşteri holüyle sınırlı olarak iç mekân, fotoğraf ve çizimler ile belgelenmiştir. Mongeri'nin aynı dönemde Anadolu'nun farklı kentleri için tasarladığı banka örneklerine yer verilerek Eskişehir Şubesi’nin dönemin mimari anlayışı içindeki yeri değerlendirilmiştir. Mongeri’nin Eskişehir Şube Binası tasarımında Birinci Ulusal Mimarlık akımını temsil eden unsurlarından hangilerini ve ne derece yansıttığ 1 irdelenmiştir. Bu unsurların günümüze ulaşmış hâliyle akımın özelliklerini hâlen temsil edip etmediği araştırılmıştır. Alanda yapılan incelemelerde iç mekânda gerçekleştirilen değişiklikler analiz edilmiştir.

Kent kimliği için önemli bir tarihi belge niteliğinde olan yapıyı incelemeye geçmeden önce temsil ettiği akımın özelliklerine değinilecektir.

\section{Birinci Ulusal Mimarlık Akımı}

18. yüzyıldan itibaren Osmanlı İmparatorluğu’nda Avrupa hayat tarzına olan ilgi oldukça artmış, zamanla bu durumun Osmanlı kültürüne ve mimarisine olumsuz etkileri olduğu konusunda tartışmalar ortaya çıkmıştır. Avrupa'da Endüstri ve Fransız Devrimleri'nin etkisiyle, yeni bir sosyo-kültürel yapı oluşmaya başlamış, Osmanlı İmparatorluğu'nda da değişimler yaşanmıştır. 
Ulusçuluk, Avrupa'da özellikle Napolyon'un hâkimiyetinin artmasıyla önce İtalya ve Almanya' da oluşmaya başlamış, on dokuzuncu yüzyıl boyunca da yayılmıştır. ${ }^{1}$ Osmanlı İmparatorluğu'nda da gittikçe artan yabancı mimarların kentte eklektik bir tarz oluşturması mimaride kimlik arayışlarının ortaya çıkmasına neden olmuştur. 1908'de II. Meşrutiyet'in ilan edilmesiyle birlikte, Ziya Gökalp'in düşünceleri mimarları ve sanatçıları etkilemiştir. ${ }^{2}$ Osmanlı'nın son dönemlerinde, mimaride ulusal bir kimlik oluşturma çabalarıla, özellikle Klasik Osmanlı dönemi üslubuna ait öğeler içeren bir akım başlatılmıştır. Önceleri bu akım "Milli Mimari Rönesansı", "Neoklasik Türk Üslubu", "Milli Mimari Üslubu" gibi isimlerle anılmıştır. Daha sonra Birinci Ulusal Mimarlık olarak adlandırılan akım, Türkiye'deki mimarlık söylemi ve pratiğine 1910'lu yıllardan 1930'lara kadar egemen olmuştur. ${ }^{4} \mathrm{Bu}$ akımın öncüleri Mimar Kemaleddin Bey, Vedat Bey (Tek), Arif Hikmet Bey (Koyunoğlu)'dir. İstanbul doğumlu İtalyan asıllı mimar Giulio Mongeri de bu üsluba dâhil edilmektedir. Mongeri'nin hocası Boito'nun ulusalcılığın yeniden canlanmasına dair düşünceleri dönemde etkili olmuştur. ${ }^{5}$ Başkent Ankara' da kamu yapılarının inşası ile bu üslubun kullanımı yoğunlaşarak Erken Cumhuriyet dönemini yansıtan mimari miras öğelerini oluşturmuştur. ${ }^{6}$

“Birinci Ulusal Mimarlık” tanımlaması ilk kez 1970’li yıllarda kullanılmaya başlanmış, 1973'ten itibaren Metin Sözen ve 1976'dan sonra Yıldırım Yavuz terimin yaygınlaşmasına önemli bir katkı sağlamışlardır. İlk dönemde yaklaşık 1923-1935 yılları arasında yapılan eserler üzerinden Türk mimarlığındaki üslup özellikleri ve görsel söylemler ön plana çıksa da zaman içinde bu akıma ilişkin çalışmalar arttıkça bu ifadenin kapsamının genişlediği görülmektedir. ${ }^{7}$

Yavuz'un, bu akımın biçimsel özelliklerine dair belirlediği beş temel ilkeye göre, yapılar orta doğrultulara göre bakışık bir şekilde planlanmaya çalışılmış ve ana girişler bu doğrultuda yerleştirilmiş, uygun olmayan arsalarda ise ön yüzün bakışı biçimde düzenlenmesine özen gösterilmiştir. Sokaktan algılanan yüzlerin bezemelerinin diğer yüzlerine göre görkemine daha çok önem verilmiş, vurgu için orta doğrultu ve köşeler cumba ya da köşe kuleleri ile belirginleştirilmiş, yapıda çağdaş malzeme kullanılsa da

1 Yildırım Yavuz, Imparatorluktan Cumhuriyete Mimar Kemaleddin 1870-1927 (Ankara: TMMOB Mimarlar Odası ve Vakıflar Genel Müdürlüğü Ortak Yayını, 2009), 11.

2 İlhan, Tekeli, “Türkiye'de Mimarlı̆̆ın Gelişiminin Toplumsal Bağlamı,” Modern Türk Mimarlı̆ğ 1900-1980, ed. Renata Holod, Ahmet Evin ve Süha Özkan (Ankara: TMMOB Mimarlar Odası Yayınları, 2007), 16; Selda Kızıldere ve Metin Sözen, "İstanbul'da Birinci Ulusal Mimarlık Dönemi Yapıları'nın Kent Bütünü İçindeki Yerinin Değerlendirilmesi," ITÜ Dergisi/b, Sosyal Bilimler 2/1 (2005), 88.

3 Metin Sözen ve Mete Tapan, 50 Yllın Türk Mimarisi (İstanbul: Türkiye İş Bankası Kültür Yayınları, 1973), 99, 105.

4 İnci Aslanoğlu, Erken Cumhuriyet Dönemi Mimarlığ 1923-1938 (İstanbul: Bilge Kültür Sanat Yayınevi, 2010), 30.

5 Paolo Girardelli, "Italian Architects in an Ottoman Context: Perspectives and Assessments," İstanbul Araştırmaları Ylllığı 1 (İstanbul: İstanbul Araştırmaları Enstitüsü, 2011), 110.

6 Yıldırım, Yavuz, “1923-1940 Arası Ankara' da Mimari,” Ankara Ankara, ed. Enis Batur (İstanbul: Yapı Kredi Yayınları, 1994), 202.

7 Ali Cengizkan, Modernin Saati-20. Yüzyllda Modernleşme ve Demokratikleşme Pratiğinde Mimarlar, Kamusal Mekan ve Konut Mimarllğı, Mimarlar Derneği 1927 Yayınları (İstanbul: Boyut Yayın Grubu, 2002), 61, dipnot 1. 
kesme taş kaplama ya da kesme taş görünümü verecek şekilde sıvayla derzlenmiştir. Cepheler taş kuşaklarla üç yatay bölüme ayrılmıştır. Yavuz burada Rönesans dönemi Batı mimarisinden etkileşime dikkat çekmektedir. Her bölümün kendi içinde bütün oluşturduğunu, ancak katlarda değişik pencere biçimleri kullanıldığını, yerden çatıya kadar düşey olarak düzenlenen yüzey dilimlerinin yinelenerek ritim oluşturduğunu belirtmiştir. Ayrıca kütle organizasyonunda Batı'daki çözümlemeler kullanılırken cephelerde yoğunlukla 15. ve 16. yüzyıl Osmanlı mimarisinden unsurların seçildiğini tespit etmiştir. Pencere biçimlerinde iki veya üç merkezli sivri kemerler, penci, düz veya atk1, basık, sepet kulbu kemerler ve nadir kullanılan kemer türleri olmak üzere altı farklı kemer tipolojisi olduğunu vurgulamıştır. Bunların içinde Bursa kemerleri de bulunmaktadır. Bu döneme ait yapılarda kullanılan bezeme öğeleri olarak tepelikler, silmeler, sütunlar, sütun başlıkları, bezemeli veya yalın konsollar, demir, taş veya mermerden yapılan korkuluklar, kemer köşelerine uygulanan bezemeler, köşe sütunceleri tanımlanmıştır. ${ }^{8}$ İç mekânlarda da Selçuklu ve Klasik Osmanlı dönemi motifleri, kabartmalar, alçı tavan süslemeleri, mukarnaslı sütunlar, kalem işleri ve çini panolar kullanılmıştır. İstanbul'da bu akımın öncüleri arasında Mimar Vedat (Tek) tasarımı "Posta ve Telgraf Nezareti Binası” (1909), ardından "Defter-i Hakani Binası” yer almaktadır."

Yirminci yüzyıl ortalarına doğru teknolojik ve ekonomik gelişmelerle birlikte mimari anlayış da değişim geçirmiştir. Modernizm, mimariye işlevsellik ve sadelik özelikleriyle yön vermeye başlamıştır. Ulusal bir dil oluşturma amacıyla ortaya çıkan Birinci Ulusal Mimarlık akımı, Batı'da başlayan bu değişimlere uyum ve ortaya çıkan mekânsal gereksinimleri karşılayacak çözümleri sağlayamamıştır. 1927'den itibaren mimarlık pratiğinde ve eğitiminde aktif rolü bulunan Ernst Arnold Egli, Clemens Holzmeister gibi yabancı mimarların bu dönemin mimari anlayışının değişiminde etkisi olmuştur. Genç Cumhuriyet yönetimi ve reformların etkisiyle 1930'larda bu akım çeşitli nedenlerle sonlanarak modern yapım teknikleri ve biçimler ön plana çıkmıştır. ${ }^{10}$ Mimarideki bu gelişmelere ayak uyduramayarak tasarım yapmayı bırakan mimarlardan birisi de Guilio Mongeri’dir.

\section{Mimar Giulio Mongeri}

İtalyan kökenli mimar Giulio Mongeri (1873-1951) İstanbul'da doğmuş, eğitimini İtalya Brera Güzel Sanatlar Akademisi'nde tamamlamıştır. ${ }^{11}$ Mongeri, mimar, mimarlık tarihçisi ve restoratör Camillo Boito’nun öğrencisidir ve çalışma hayatı boyunca

8 Yavuz, Mimar Kemalettin ve Birinci Ulusal Mimarlık Dönemi (Ankara: ODTÜ Mimarlık Fakültesi Basım İşliği, 1981), 62, 64-65, 68, 70, 71.

9 Yıldırım Yavuz ve Süha Özkan, “Osmanlı Mimarlı̆̆ının Son Yılları,” Tanzimattan Cumhuriyete Türkiye Ansiklopedisi, c. 4 (İstanbul: İletişim Yayınları, 1985), 1082.

10 Bu konuda görüşler ve tartışmalar için bkz. Sedad Hakkı Eldem, "Elli Yıllık Cumhuriyet Mimarlı̆̆ı," Mimarlkk Dergisi, 121 (11-12) (1973), 6; Cengizkan, Modernin Saati-20. Yüzyllda Modernleşme ve Demokratikleşme Pratiğinde Mimarlar, Kamusal Mekan ve Konut Mimarlı̆̆l, 86.

11 Mongeri ve ailesi hakkında ayrıntılı bilgi için bkz. Özlem İnay Erten, Şişli'de Bir Konak ve Mimar Giulio Mongeri/ A Mansion in Şişli and Architect Giulio Mongeri (İstanbul: Bozlu Sanat ve Yayınc1lık, 2016), 28-110. 
onun ilkelerini benimsemiştir. ${ }^{12}$ İstanbul İstiklal Caddesi’nde Saint Antonio Kilisesi projesini (1906-1911) Edoardo De Nari ile birlikte gerçekleştirmiştir. ${ }^{13}$ İlerleyen y1llarda bina yapımı ve organizasyonu konusunda yoğun birikimleri olan Mongeri'nin Sanayi-i Nefise Mektebi (kuruluşu 1882)'nde ilk Türk hocalarından Vedat Tek'in yerine ataması yapılarak eğitim verdiği dönem başlar. ${ }^{14}$

Mimar Vedat Tek, Avrupa'daki eğitiminden döndükten sonra, Sanayi-i Nefise Mektebi'nde aralıklarla yaklaşık 30 yıl hocalık yapmıştır. 1899 yılında Sanat Tarihi muallimliğine, 1908'de ise Fenn-i Mimari eğitmenliğine atanmış, bu görevden 1910'da istifa etmiş ancak 1911 'de amel-i mimari (mimari atölye eğitimcisi) olarak atanmış, sonrasında ise görevden alınmıştır. Görevden alınmasının sebebi ise Mongeri'nin ve hocas1 Alexandre Vallaury (1850-1921)'nin bu okuldaki görevlerine geri dönmeleridir. Vedat Tek, 1922-1930 yılları arasında farklı dönemlerde eğitmenlik görevini sürdürmüştür. Mongeri de Sanayi-i Nefise Mektebi’nde neredeyse aynı dönemlerde mimarlık atölyelerinde eğitim vererek bir kuşağın mimarlık anlayışında etkili olmuştur. ${ }^{15}$ Sanayi-i Nefise Mektebi kurucu öğretmenlerden Alexandre Vallaury, 1908'e kadar eğitim verdiği süreçte mimarlık bölümü eğitiminin ilkelerini oluşturmuştur. ${ }^{16}$ Mongeri'nin burada Vallaury’ nin eğitim ilkelerini benimseyerek 1909 ile 1928 yılları arasında eğitmenlik yaptığı bilinmektedir. ${ }^{17} \mathrm{Bu}$ dönem içinde Trablusgarp ve Birinci Dünya Savaşı nedeniyle 1911-1913 ve 1915-1922 yılları arasında görevine ara vermek zorunda kalmıştır. ${ }^{18}$ Savaş nedeniyle Mongeri'ye öğrenciler tarafindan eleștirel yaklaşıldığ 1 ileri sürülse de ${ }^{19}$ Mongeri'nin öğrencilerine iş olanağ ${ }_{1}$ sağladığı, sevgi ve saygıyla anıldığı bilinmektedir. ${ }^{20}$ İstanbul'da tasarladığı yapılar arasında, "Bulgur Palas (1912)", "Assucurazioni Generali Han (1909-1913 aras1)", "Nurettin Bey Pavyonu (1924)", "Haseki Hastanesi”, "Taksim Cumhuriyet Anıtı kaidesi (1928)" gibi eserler bulunmaktadır. ${ }^{21}$ Mongeri’nin eserleri üç

12 Paolo Girardelli, "Italian Architects in an Ottoman Context: Perspectives and Assessments," 110; C. Can, "İstanbul'da 19. Yüzyıl Batılı ve Levanten Mimarların Yapıları ve Koruma Sorunları" (Doktora Tezi, Yıldız Teknik Üniversitesi, 1993), 338.

13 Sennur Sentürk, Cengiz Can ve Paolo Girardelli, "Yașayan Cizgiler": Sant'Antonio Kilisesi Mimari Sergisi/ "Segni Essenziali": Disegni Architettonici Della Chiesa di Sant'Antonio. İstanbul İtalyan Kültür Merkezi (İstanbul: Yapı Kredi Yayınları, 1996), 16.

14 Vilma, Fasoli, "Giulio Mongeri Edoardo De Nari and the "Societâ Anonima Ottomana Costruzioni" (S.A.O.C.)," Italian Architects and Builders in the Ottoman Empire and Modern Turkey: Design Across Borders, ed. Paolo Girardelli and Ezio Godoli (Newcastle: Cambridge Scholars Publishing, 2017), 214; Afife Batur, M. Vedat Tek: Kimliğin İzinde Bir Mimar (İstanbul: Yapı Kredi Yayınları, 2003), 233.

15 Afife Batur, M. Vedat Tek: Kimliğin İzinde Bir Mimar, 233, 235.

16 M. Servet Akpolat, "Fransız Kökenli Levanten Mimar Alexandre Vallaury" (Doktora Tezi, Hacettepe Üniversitesi, 1991), 15

17 Mustafa Cezar, Typical Commercial Buildings of the Ottoman Classical Period and the Ottoman Construction System (İstanbul: Türkiye İş Bankası Kültür Yayınları, 1983), 24.

18 Özlem İnay Erten, Sișli'de Bir Konak ve Mimar Giulio Mongeri, A Mansion in Sișli and Architect Giulio Mongeri, 72.

19 Tanyeli, Mimarlı̆gn Aktörleri Türkiye 1900-2000 (İstanbul: Garanti Galeri, 2007), 375.

20 Özlem İnay Erten, Şişli'de bir Konak ve Mimar Giulio Mongeri/ A Mansion in Şişli and Architect Giulio Mongeri, 73.

21 Can, "İstanbul' da 19. Yüzyıl Batılı ve Levanten Mimarların Yapıları ve Koruma Sorunları," 339; Erten, Şişli'de Bir Konak ve Mimar Giulio Mongeri/ A Mansion in Şişli and Architect Giulio Mongeri, 69. 
üslubu yansıtmaktadır: Bunlardan ilki İstanbul'daki ilk yıllarında gerçekleştirdiği İtalyan mimarlığının etkili olduğu "Saint Antonio Kilisesi ve Apartmanları (1906-1913)", “Karaköy Palas (1920)", "Majik Sineması (1914-1920)”, "Maçka Palas (1922)” gibi projeleri içeren "Batı Etkili Eklektik Üslup"; ikincisi Selçuklu ve Osmanlı dönemi etkilerinin görüldüğ̈̈ “Birinci Ulusal Mimarlık Akımı” olarak tanımlanan üsluptaki "Şişli Mongeri Evi (1925)" ile özellikle Ankara'da yaptığı bankalardır. Mimari çalışmalarının son dönemini yansıtan "Modern Mimarlık" etkisindeki yapıları ise "Bursa Çelik Palas Oteli ve Kaplıcası (1935)” ve Nişantaşı'ndaki kendi evidir. ${ }^{22}$ Galata Voyvoda Caddesi’ nde bürosu bulunan Giulio Mongeri, 1920'li y1llarda Birinci Ulusal Mimarlık akımı anlayışında Ankara' da “Osmanlı Bankası (1926)", "İş Bankası (1929)”, "Ziraat Bankası (1929)", "Tekel Baş Müdürlüğü Binası (1928)” gibi eserler vermiştir. Ziraat Bankası için gerçekleştirdiği tasarımlar arasında Ankara'da, "Lojman ve Ameli Bankacılık Mektebi" binaları ve pek çok kentteki şube binaları yer almaktadır. ${ }^{23}$ 1926' da Türkiye İş Bankası ile gerçekleştirdiği iş birliği sonucunda kurumun proje ve inşaat takibi görevini üstlenmiştir. ${ }^{24}$ Dünyada modernizmin yaygınlaştığı dönemde "Bursa Çelik Palas Oteli'ni ve Kaplıcalarını (1935)" yapan Mongeri, öğrencileriyle bir konuşmasında “klasik ekolde yetiştiği için modern akımı benimseyemediğini” aktarmıştır. Ardından Sanayi-i Nefise Mektebi'nden ayrıldığı ve mimarlığa son verdiği bilinmektedir. ${ }^{25}$ Bu kararı vermesindeki en önemli etken, Ankara'da gerçekleştiremediği projelerdir. Ankara Müftüsü’nün önderliğinde 1921 yılında Ankara halkı tarafından Mustafa Kemal Atatürk'e hediye edilen, eski bir bağ evi olan Çankaya'daki köşkte 1924 yılında Vedat Tek birtakım yapısal değişiklikler gerçekleştirse de 1930 yılında köşkün büyütülmesi gerekmiştir. Bu kapsamda Mongeri öneriler getirmiş ancak yapısal sorunlar çıkaracağı için kabul görmemiştir. Mongeri, 1926 yılında da “Gazi Köşkü Projesi” için Osmanlı yapılarından izlerin bulunduğu Birinci Ulusal Mimarlık Akımı üslubunda bir proje sunmuştur ancak Ankara'nın modern bir şehir olması gerektiğine inanan Atatürk, proje için teşekkürlerini ileterek projeyi kabul etmemiştir. Modernleşme ve gelişme sürecinde olan başkentteki yeni Cumhurbaşkanlığ1 Köşkü için Clemens Holzmeister (1886-1983) tarafından yeni bir anlayışla tasarlanan projenin kabul edilmesinin ardından devletin bu akıma desteğinin kesildiği ve akımın sonlandığı izlenmektedir. ${ }^{26}$ Mimar Giulio Mongeri, 1951'de Venedik'te vefat etmiştir. ${ }^{27}$

22 Erten, Şişli'de Bir Konak ve Mimar Giulio Mongeri/ A Mansion in Şişli and Architect Giulio Mongeri, 69.

23 Nurettin Hazar, Ziraat Bankası (Ankara: Fon Matbaas1, 1986), 315-316.

24 Erten, Şişli'de Bir Konak ve Mimar Giulio Mongeri/ A Mansion in Şişli and Architect Giulio Mongeri, 75.

25 Behçet Ünsal, “İsmet Barutçu ve Nizamettin Doğu’dan Anılar,” Arkitekt 2 (330) (1968), 93.

26 Yıldırım Yavuz, “Ankara Çankaya'daki Birinci Cumhurbaşkanlığı Köşkü,” Tarih İçinde Ankara II Aralık 1998 Seminer Bildirileri (Ankara: ODTÜ Mimarlık Fakültesi Yayınları, 2001), 362; Erten, Şişli’ de bir Konak ve Mimar Giulio Mongeri/ A Mansion in Şişli and Architect Giulio Mongeri, 79.

27 Damla Çinici, Türkiye Cumhuriyeti Mimarlığının Modernleşme Sürecinde Mimar Giulio Mongeri: Bursa Çelik Palas Oteli ve Kaplıcası (Bursa: Nilüfer Belediyesi Yayınları, 2017), 16. 


\section{Ziraat Bankası Eskişehir Şube Binası}

Eskişehir'de bir banka binası ihtiyacı, Osmanlı devletinin sonlarında demiryolunun yapılması ve ekonomik gelişmelerin hız kazanmasıyla ortaya çıkmıştır. Kent, Cumhuriyet'in kuruluşu ile sanayi, tarım, ulaşım ve madencilik sektörlerine yapılan yatırımlarla sosyo-ekonomik bir gelişme göstermiştir. ${ }^{28}$

Cumhuriyetin ilk yıllarında Odunpazarı bölgesindeki tarihi dokuya zarar verilmeden, kentin genelinde modern ulaşım sistemleri geliştirilmiş, sanayi faaliyetleri için çalışmalar yapılmış ve tren garı bölgesinde modern konut ve kamu yapıları inşa edilmiştir. Kuruluş tarihi 1888 olan Ziraat Bankası, ülkedeki gelişmelere paralel olarak hizmet ağını büyüterek 1906-1907 yıllarında Eskişehir'de şube binası açmaya karar vermiştir. ${ }^{29}$ Mimar Giulio Mongeri'nin tasarladığı, Ziraat Bankası Eskişehir Şube Binası inşaatı 1928'de başlamış, 1930 yılında Cumhuriyet'in yedinci yılı kutlamalarıyla birlikte banka 29 Ekim tarihinde açılmıştır. ${ }^{30}$ Mongeri, Ziraat Bankası şube binaları için Eskişehir ile birlikte Adana, Aydın, Kütahya ve Manisa kentlerinde de benzer projeler uygulamıştır. ${ }^{31}$

Kentin mekânsal örüntüsünde, yamaçta Kurşunlu Külliyesi (1515-1526) etrafında gelişmiş Odunpazarı geleneksel konutları ile Odunpazarı'nın aşağı düzlügü̈nde Porsuk Çayı kenarında Köprübaşı Bölgesi'ndeki tek katlı çarşı ve hamamlar kentin merkezini oluşturmaktadır. Arifiye Mahallesi 12999 Adada 2. Parselde bulunan Ziraat Bankası kentin ticaret merkezi ile Odunpazarı geleneksel konut bölgesinin ortasında bulunmaktadır. 1972'de alınan tapuda 257 Ada 55. Parsel olarak belirtilen konum bilgilerinin, Tapu Kadastro Genel Müdürlügü resmî sitesindeki verilerin güncellenmesi ile değiştiği görülmektedir. Kıbrıs Şehitleri Caddesi ile İki Eylül Caddesi'nin kesiştiği noktada ön cepheleri güneybatı ve kuzeybatı yönüne bakan yapı köşe parsel olarak yerleştirilmiştir. 1907 yılında hükümet konağı karşısındaki belediyeye ait bu arsa Ziraat Bankası'na devredilmiştir (G. 1). ${ }^{32}$

28 Zafer Koylu, “XX. Yüzyılın Başlarında Eskişehir,” Atatürk Araştırma Merkezi Dergisi 24/71 (2008), 384.

29 Şahap Sitkı İlter, Ziraat Bankası Dün-Bugün (Ankara: Başnur Matbaası, 1967), 18; Başbakanlık Osmanlı Arşivi, 00016.00008.001, 16.11.1324 (1906-1907).

30 Hazar, Ziraat Bankası, 326.

31 Duygu Saban, “Giulio Mongeri 'nin Banka Tasarım İlkeleri-Ziraat Bankası Adana Şubesi Örneği,” Çukurova Araştırmaları Dergisi, 2/2 (2016), 121.

32 Başbakanlık Osmanlı Arşivi (BOA), 00016.00008.001, 16.11.1324 (1906-1907). 


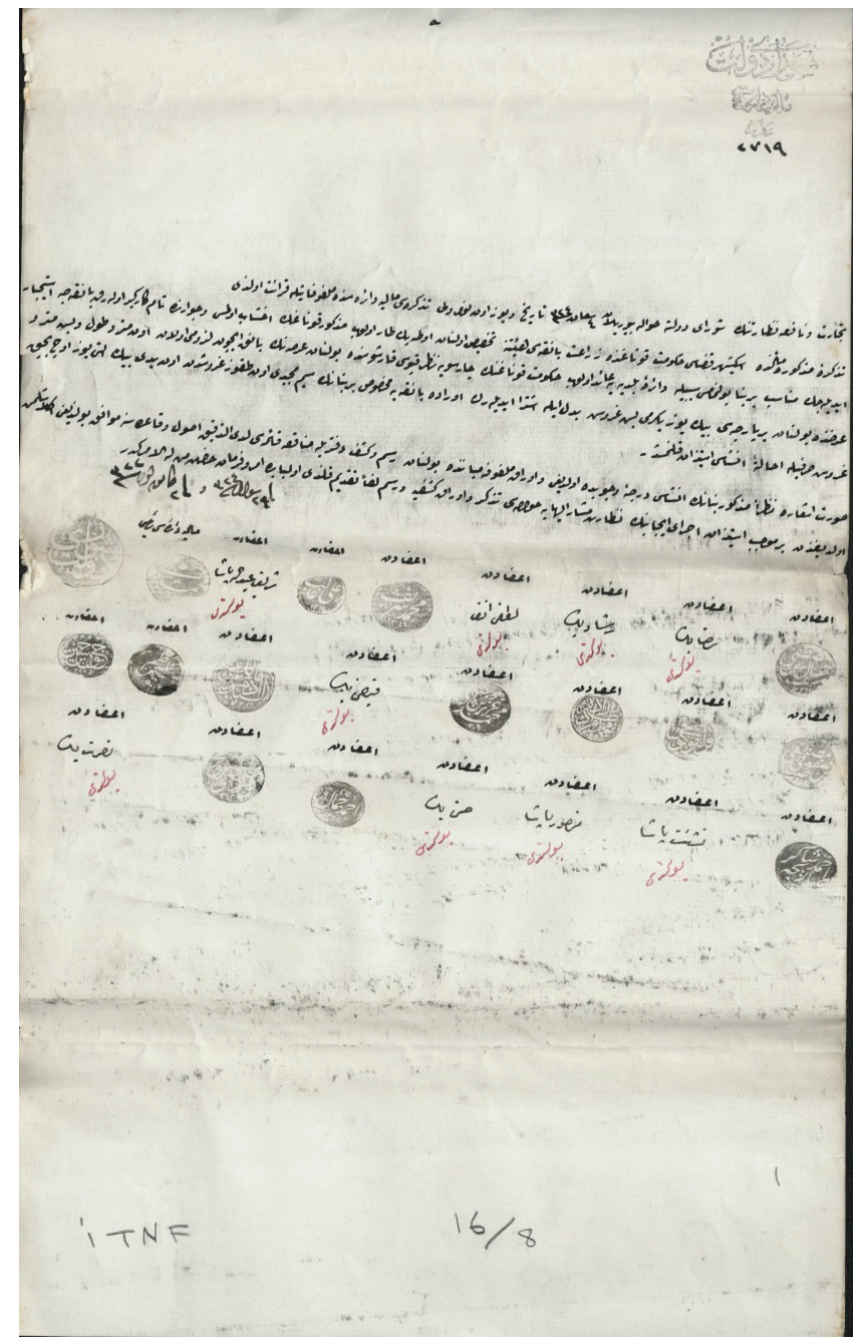

G. 1. Eskişehir Hükümet Konağı'nın karşısında Belediyeye ait arsadan miktar-1 kafi bir mahal ifrazıyla Ziraat Bankası ittihaz olunmak üzere daire inşas1, BOA. İ. TNF. 00016.00008.001.001 (Başbakanlık Osmanlı Arşivi, 1906-1907).

1930'ların başında civardaki en büyük yapı olan Ziraat Bankası binasının karşısındaki meydanda hayvan ve zahire pazarları kurulmaktadır (G. 2). Bina inşa edildiği tarihte olduğu gibi günümüzde de kent merkezinde yer almaktadır. İlk kez 1945’te hazırlanan imar planına göre ${ }^{33}$ Ziraat Bankası'nın bulunduğu alanda Belediye binası ve Valilik binası yer almaktadır. Bu yapıların ortasındaki eski pazar alanı ise günümüzde Vilayet Meydanı olarak kullanılmaktadır.

33 Güler Koca ve Rana Karasözen, “1945-1960 Dönemi Eskişehir Modern Kent Merkezinin Oluşumunda Öne Çıkan Yapılar,” Anadolu Üniversitesi Sosyal Bilimler Dergisi 10/3 (2010), 194. 


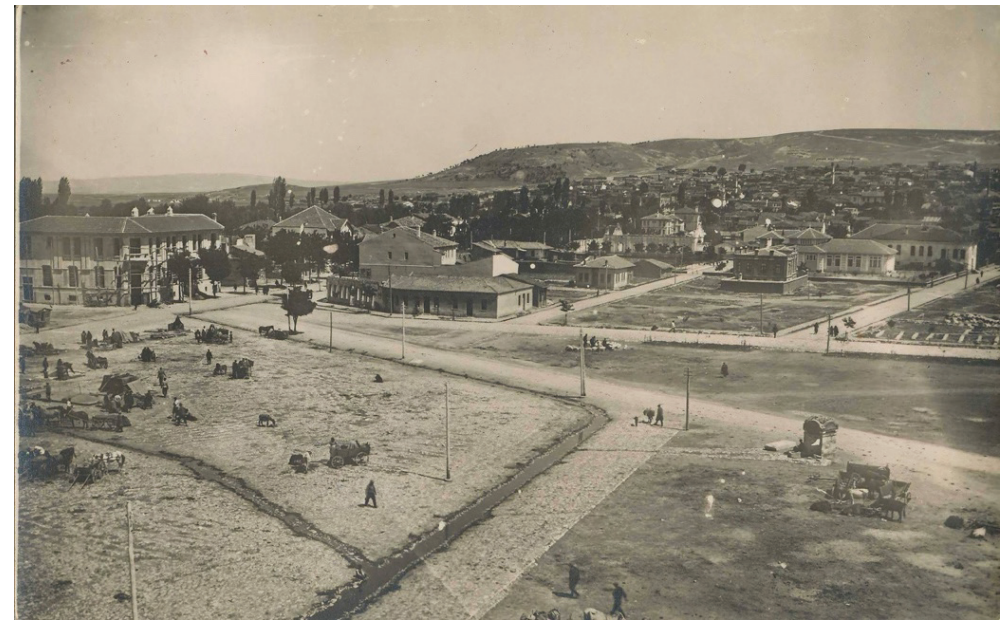

G. 2. 1930' lu yıllarda Ziraat Bankası ve Tarihi Çevre (Eskişehir Tepebaşı Belediyesi Arşivi-ETBA).

Eskişehir şube binas1, bahçesi ile birlikte toplam 1319 metrekarelik bir alan kaplamaktadır. Üç katlı yapıda bodrum, arşiv ve depo; giriş kat, banka hizmetleri için planlanmıştır. Müşteri holünde yapının mimari özelliklerinin aktarıldığı künyede birinci katın banka çalışanları için lojman olarak tasarlandığı yazmaktadır ancak günümüzde bu bölüm ofis olarak kullanılmaktadır.

Güneybatı ve kuzeybatı cephelerindeki pencere biçimleri zemin katta köşeli kemer, birinci katta kuzeybatı cephesinde iki adet, güneybatı cephesinde dört adet pencerenin üstü düz kemer formlarının içine yerleştirilerek ikili gruplar hâlinde düz ya da Bursa kemeri tipinde bezeli olarak tasarlanmıştır. Düz ve köşeli kemerli pencere biçimleri Adana ve Kütahya' daki şubelerde de görülmüştür. ${ }^{34}$ Pencerelerin yerleşimi asimetriktir ve kat seviyelerinde yükseklikleri değişkenlik göstermektedir. 


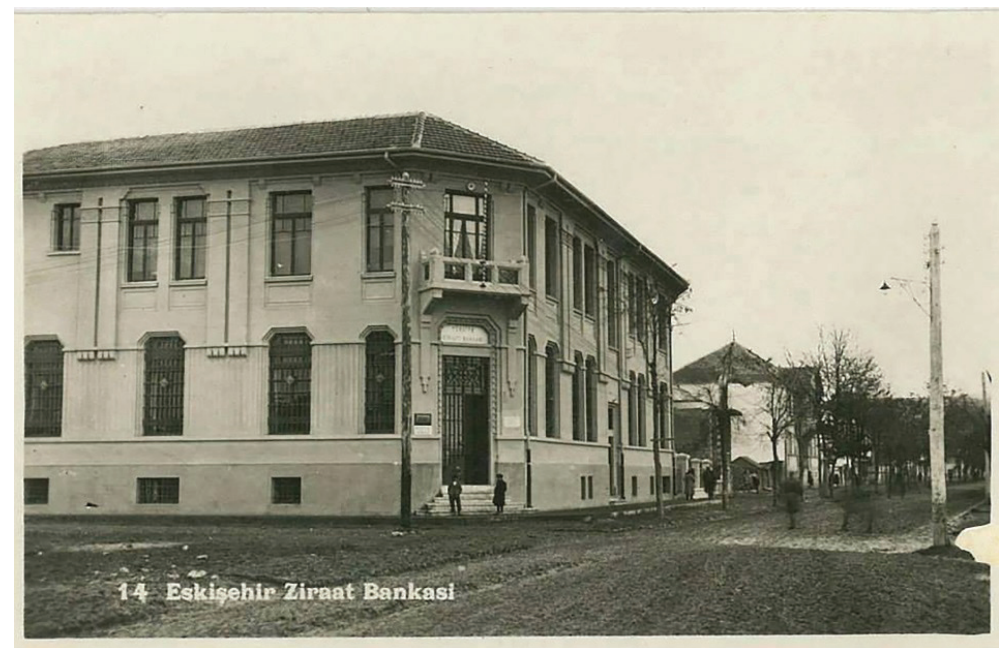

G. 3. 1930'lu yıllarda Ziraat Bankası (ETBA).

Pencere demir parmaklıklarında, Ziraat Bankası'nın 1920'li yıllardaki logosundan monogramlar, lokmalar ve Selçuklu motiflerine yer verilmiştir. Pencerelerin aralarındaki boşluklarda yer alan ikili gruplar hâlindeki plasterler, kuzeybatı cephesinde iki adet, güneybatı cephesinde dört adet olarak kullanılmıştır. Üst kısımlarında zencerek motifli kabartmalar bulunmaktadır (G.6). Plasterlerin bitimindeki yatay silmenin devamında kuzeybatı ve güneybatı cephesi boyunca düşey ince kaval silme devam etmekte ve onun altında diğerlerine kıyasla daha geniş bir yatay silme görülmektedir. Güneybatı cephesinde inşa edildiği dönemde lojman bölümüne geçiş için kullanıldığ 1 düşünülen bir adet kapı bulunmaktadır.

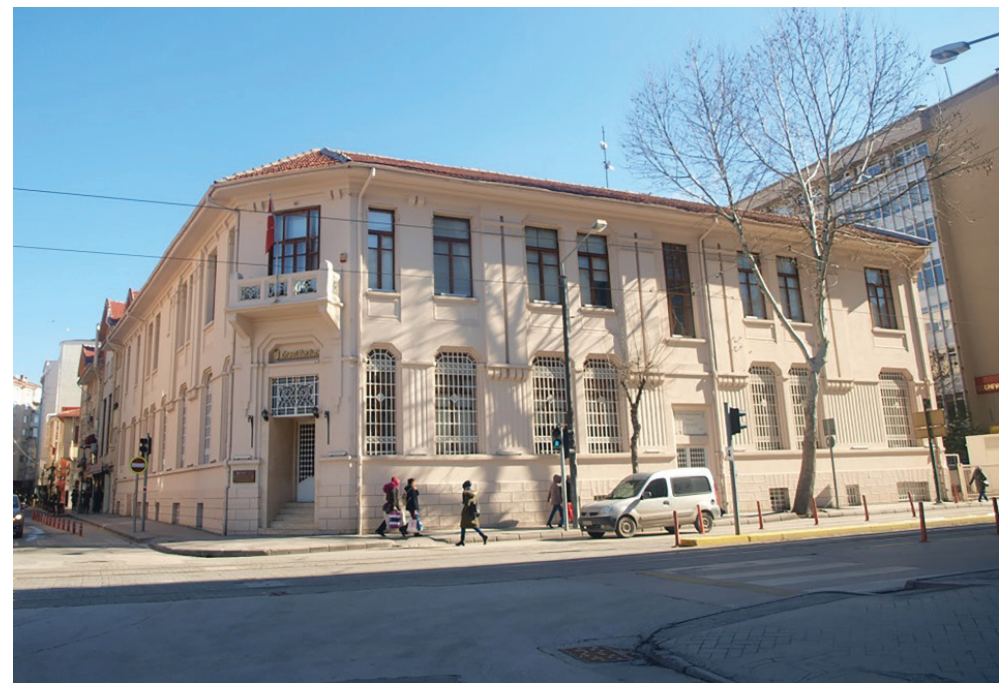

G. 4. Eskişehir Ziraat Bankası Kuzeybatı ve Güneybatı Cephesi (Rabia Temel, 2018). 
Adana Şubesi'ndeki plasterlerin üzerinde de benzer motifler görülmektedir. ${ }^{35}$ Plasterler uygulaması İzmir'de günümüzde "Türkiye Ekonomi Bankası olan Banca Commerciale (1928)" yapısında cepheyi beşe bölecek biçimde kullanılmıştır. Kapı ve pencere üstlerindeki yarım daire kemerler Mongeri'nin bu yapısındaki Neo-Rönesans akımının etkilerini göstermektedir ${ }^{36}$ (G. 8).

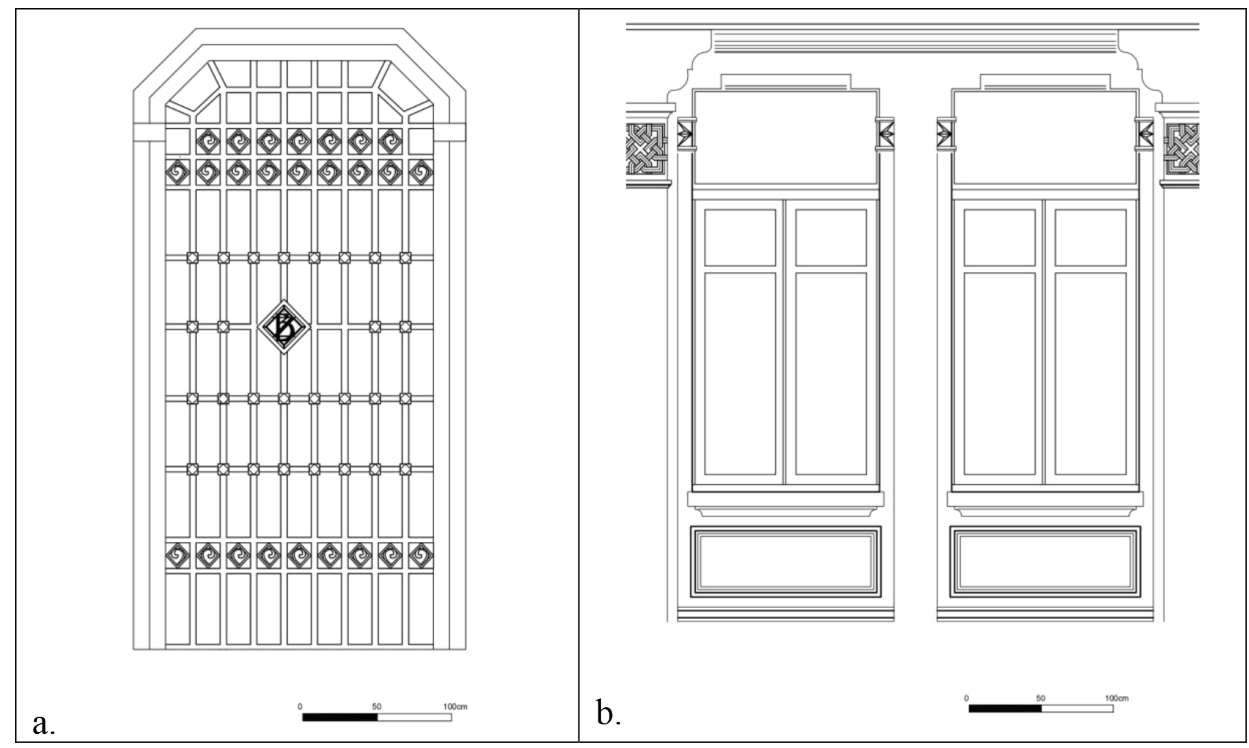

G. 5a. Zemin Kat Pencere Korkuluk Motifi; 5b. Birinci Kat Pencere Detay1 (ZBA., Çizim: Yüksek Mimar Reşat Toklu, 2013)

Eskişehir şube binasında, bu dönem yapılarında sıklıkla görüldüğü gibi arka cepheler sade bir düzenleme ile tamamlanmıştır. Güneybatı ve kuzeybatı cephelerinden bodrum üzeri iki kat olarak görünen yapının doğu cephesine bakan tarafında zemin kat üzerinde teras bulunmaktadır. 


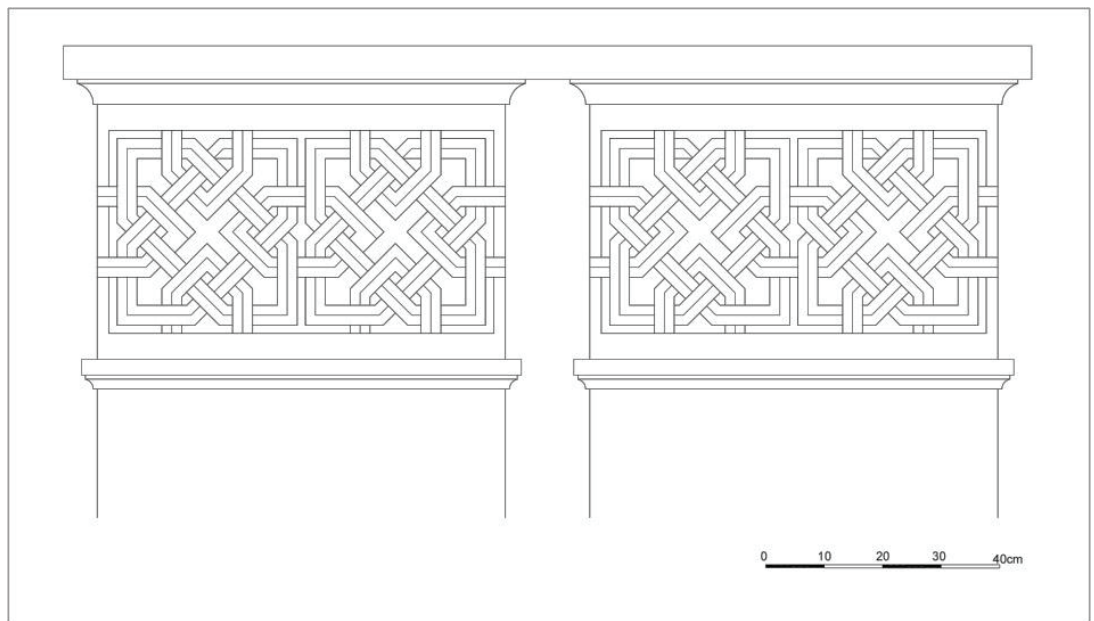

G. 6. Cephe Zencerek Motifi (ZBA, Çizim: Yüksek Mimar Reşat Toklu, 2013).

Yapının köşesindeki giriş cephesinde, giriş kapısı köşeli kemer içine kurgulanmıştır. Mongeri’nin Ziraat Bankası Adana, Aydın, Eskişehir şubesi tasarımlarında, giriş kapısının iki yanına yerleştirilen fenerler ve girişi vurgulayan mimari elemanlar, kimliği oluşturan ortak özelliklerdendir. Eskişehir şube giriş cephesindeki balkon ve altlarındaki profilli yalın konsollar dönemin cephe özelliklerini yansıtmaktadır. Balkonda babalar arasına yerleştirilmiş orijinalliğini koruduğu düşünülen ferforje motifler yer almaktadır. Aydın ve Adana şubelerinde giriş kapıları ahşaptan yapılmış, Eskişehir şubede farklı olarak ferforjeli demir kapı kullanılmıştır.

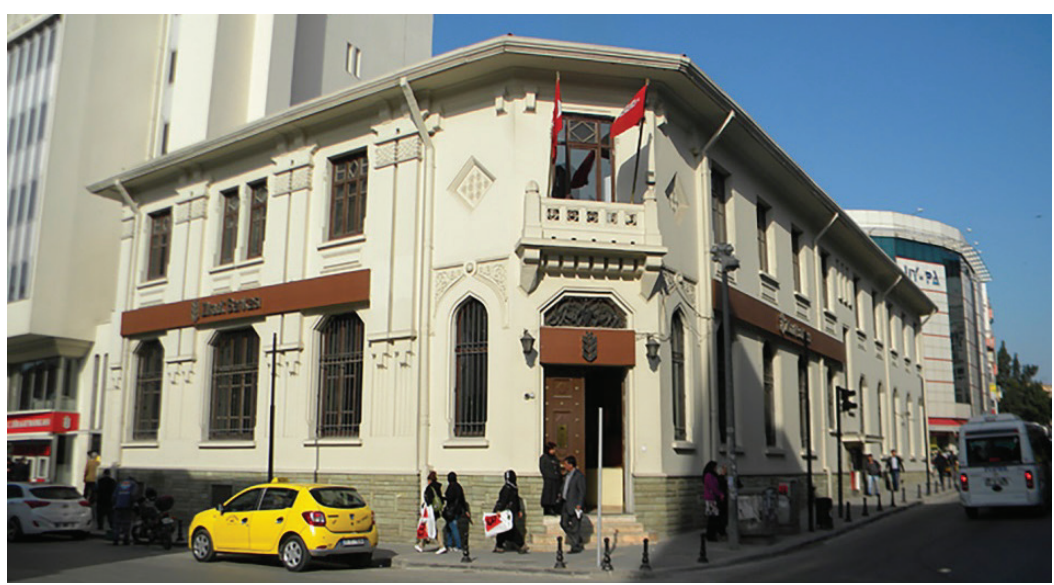

G. 7. Adana Şube Binası (Fotoğraf tarihi bilinmiyor) (Duygu Saban, "Giulio Mongeri'nin Banka Tasarım İlkeleri-Ziraat Bankası Adana Şubesi Örneği”, 121).

Kiremit çatı, köşede ana girişi vurgulayacak biçimde eğimli planlanmıştır. Üç yöne meyilli kırma çatı modeli uygulanmıştır. Geniş saçaklı yapıda Ankara Ziraat Bankası Genel Müdürlük Binası'nda uygulandığı gibi saçak altı motifleri kullanılmamıştır. 


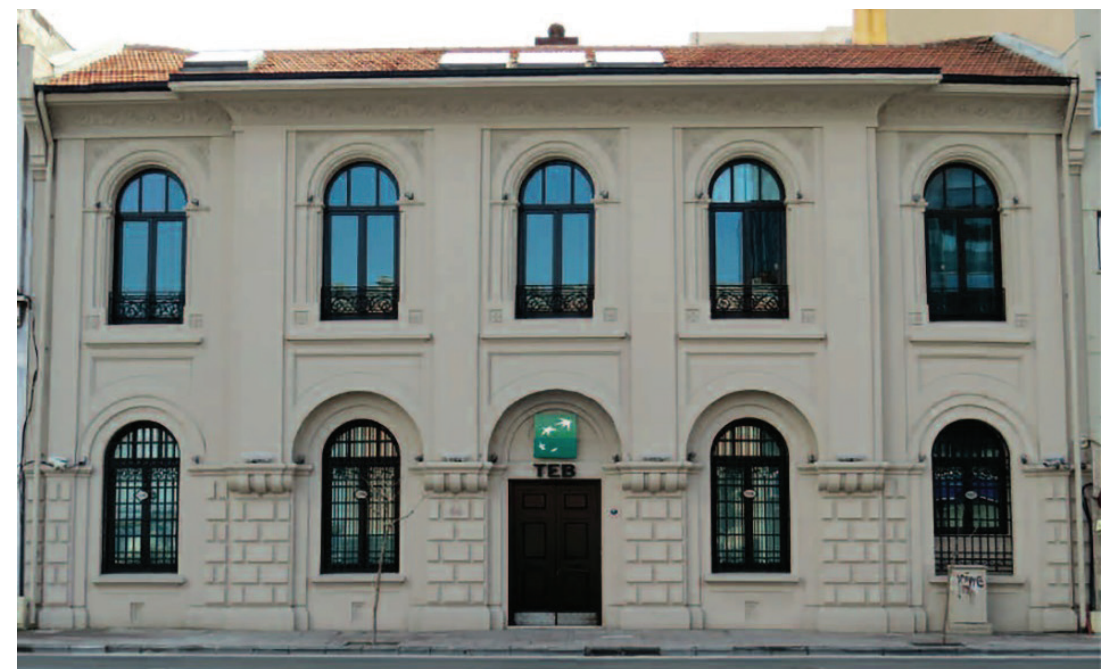

G. 8. İzmir Banca Commerciale Binası (Fotoğraf tarihi bilinmiyor) (Cenk Berkant, "İzmir'de İki İtalyan Projeci: Stefano Molli (1858-1916) ve Giulio Mongeri (1873-1953)”, 53).

Mongeri'nin tasarlamış olduğu Ziraat Bankası Eskişehir, Adana, Kütahya, Manisa ve Aydın Şube Binaları'nda benzer olarak üç katlı ve bu katlar aynı işlevlere yönelik tasarlanmıştır. ${ }^{37}$ Plan incelemesi yapılırken T.C. Ziraat Bankası İnşaat Yönetimi Bölüm Başkanlığı Arşivi’nden temin edilen 2013 yılına ait Eskişehir Şubesi tadilat öncesi mevcut durum ve tadilat projesinden yararlanılmıştır. Yapıya ait herhangi bir restitüsyon araştırması ve çizimi mevcut değildir.

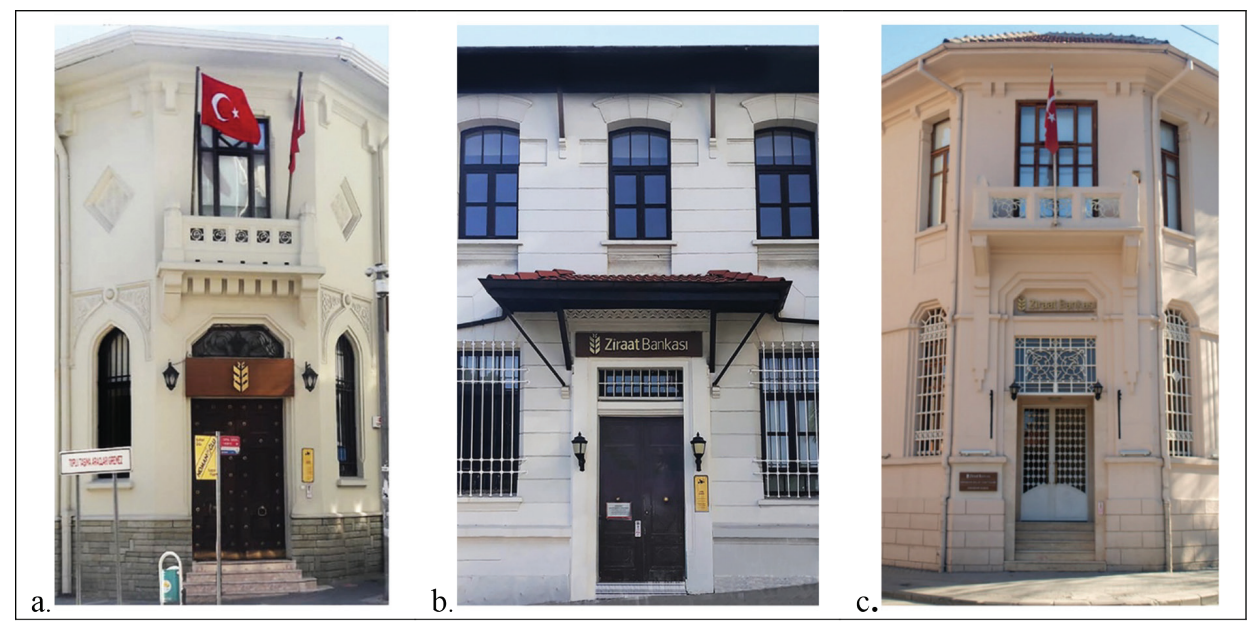

G. 9. Ziraat Bankası Şubeleri’nde Giriş Kapısı Örnekleri: 9a. Adana Şubesi Giriş Cephesi, 2020. 9b. Aydın Şubesi Giriş Cephesi, 2020. 9c. Eskişehir Şubesi Giriş Cephesi, 2018 (Rabia Temel).

37 Duygu Saban, “Giulio Mongeri’nin Anadolu’daki İzleri-Ziraat Bankası Şube Binaları,” 74. 
Zemin kata erişim batı cephesindeki köşede ana giriş kapısından ve Z02 müşteri holü ile Z13 numaralı koridorun arasında yer alan merdivenlerden yapılmaktadır. Giriş kapısının önünde yapının dışına taşan mermer döşemeli beş adet basamak bulunmaktadır. Giriş holü (Z01), geniş bir servis ve dolaşım alanına sahip müşteri holüne (Z02) açılmaktadır. Kapı ile ayrılan bu iki bölüm arasında üç basamak bulunmaktadır. Zemin kat 10 oda, açık ofis bölümü, müşteri holü ve personel tuvaletlerinden oluşmaktadır. Yerleşim planı saat yönünde incelenmiştir. Giriş holünden müşteri holüne girildiğinde kuzey yönünde ilk olarak banka personeli için soyunma odaları ve tuvaletlerin bulunduğu koridor, holden açılan bir kapı ile ayrılmıştır. Kapının bulunduğu aks boyunca duvar devam etmektedir. Servis bankoları bu duvarın önüne konumlandırılmıştır. Doğu yönünde otoparka bakan cepheye paralel olarak personel yetkilileri ve operatörler için açık çalışma alanı vardır. Z02 müşteri holüne bakan bir adet servis bankosunun bulunduğu oda, bankacılık hizmetleri için ayrılmıştır. Odanın bitiminde günümüzde bir kapı ile bölünen Z13 koridoru uzanmaktadır. Bu koridordan saat yönüyle sırasıyla Z12 sistem odası, Z11 toplantı odası, Z10 kat arşivi, Z09 sigorta servisine erişim sağlanmaktadır. Yapının güneybatı cephesine bakan bölümde merdiven sahanlığının bitişiğinde müdür odası (Z08) yer almaktadır. Müdür odasının ardından Z07 sekreter odası bulunmaktadır. 


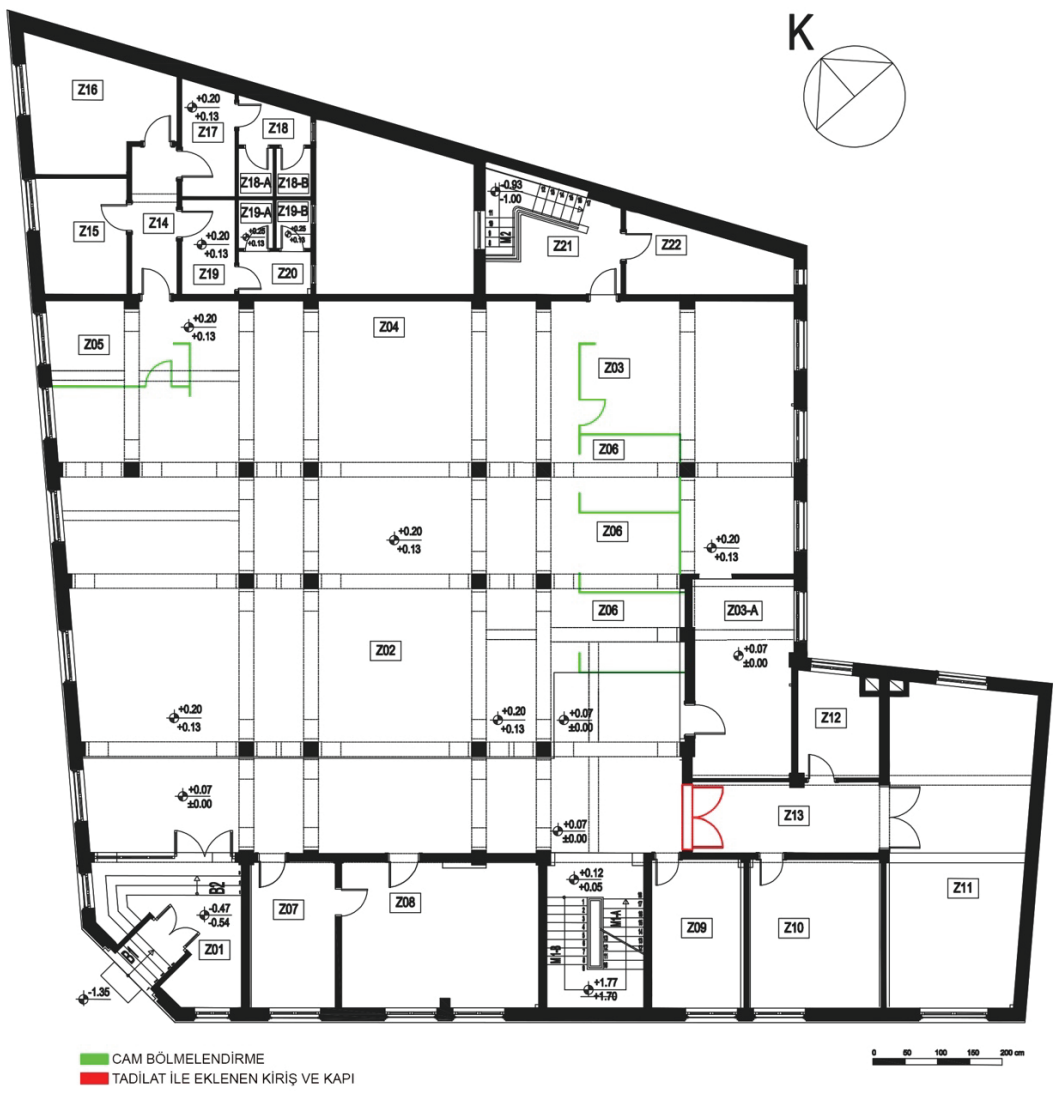

G. 10. Eskişehir Ziraat Bankası İşlenmiş Zemin Kat Tadilat Sonrası Plan Şeması. (ZBA., Çizim: Yüksek Mimar Reşat Toklu, 2013'den Rabia Temel tarafından işlenerek çizilmiştir).

Mongeri, tasarımında yapının kuzeydoğu ve güneybatı cephe duvarları boyunca çalışma mekânları konumlandırarak ortada dikdörtgene yakın bir müşteri holü oluşturmuştur. Holde, dönem özellikleri, sütunlar, başlıklar ve kemerlerde yoğun biçimde yansıtılmıştır. Erken Cumhuriyet döneminde genellikle simetrik plan şeması kullanılmış olsa da, bu yapı köşe parselde bulunduğu için simetri uygulanmamıştır.

Parselin güneyinde ATM ve bahçe bulunmaktadır. Yapının sınırları bahçe duvarı ile çevrilmiştir. Otopark olarak kullanılan bahçeye giriş, güneybatı cephesindeki İki Eylül Caddesi'ne bakan otomatik demir kapı ile sağlanmıştır. 


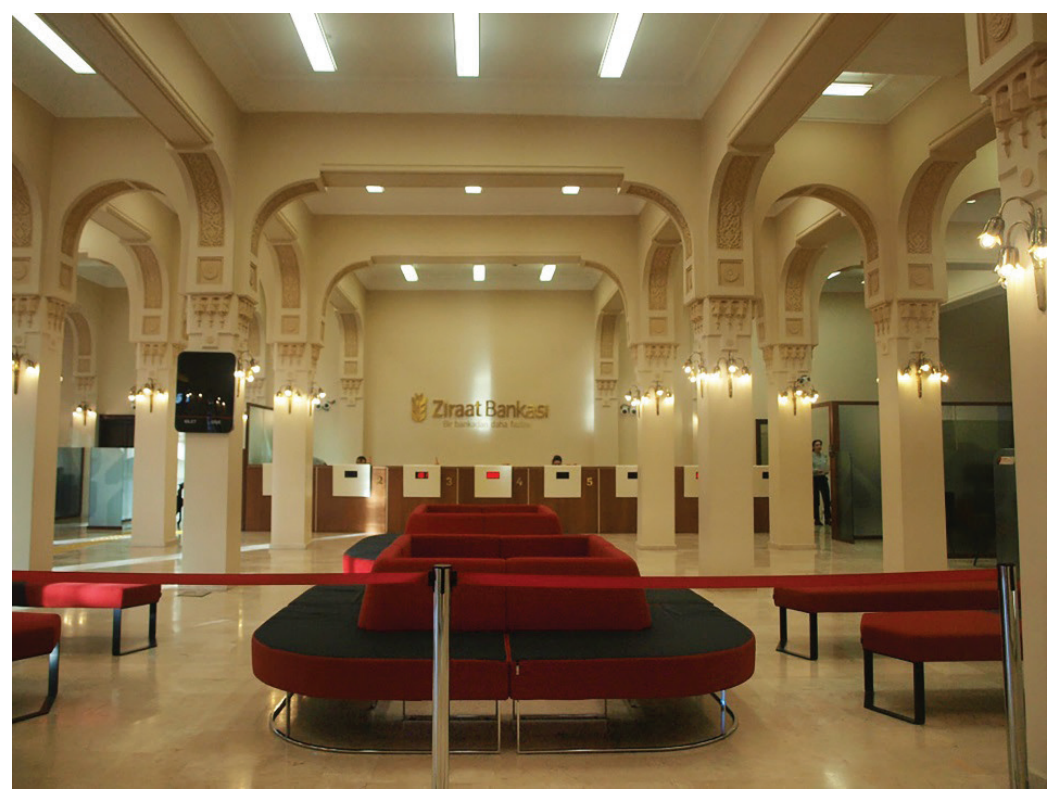

G. 11. Eskişehir Ziraat Bankası Zemin Kat Z02 Müşteri Holü. (Rabia Temel, 2018).

Birinci Ulusal Mimarlık Akımı döneminde, cephe süslemelerine kıyasla iç mekânlar daha sade tutulmuştur. Öte yandan bu dönemde inşa edilen banka binalarının iç mekân süslemeleri diğer kamu yapılarına göre daha yoğundur. ${ }^{38}$ Ziraat Bankası Eskişehir Şube iç mekân tasarımında da Z02 müşteri holünde kullanılan sütunlar, kemerler ve oda kapılarının haricinde sadelik hâkimdir. Yapının iç mekânında, Birinci Ulusal Mimarlık dönem özelliklerine uygun olarak yüksek tavan uygulanmıştır. Genelde nadir kullanılan tiplerden olan geniş aynalı Bursa tipi kemerler ${ }^{39}$ yapının iç mekânında en dikkat çekici unsurlardandır. Alt kısımları hatayi motifli kabartmalarla bezelidir. Geçişlerin alt kısmında kare pano içinde gülçe motifli rozet görülmektedir. Sütunlar geçiş mukarnas bezemeli olup altına küçük rozetler yerleştirilmiştir.

Zemin malzemesi olarak günümüzde mermer kaplama görülmektedir. Ancak yapının mevcut durum projesinde birinci kat zemininde mozaik olmasından, mekân organizasyonu yönünden benzerlik gösteren Ankara Osmanlı Bankası zemininde mozaik uygulanmasından dolayı yapının ilk hâlinde müşteri holü zemininde mozaik kullanıldığı düşünülmektedir. Hol tavanı düz betonarme döşeme üzeri plastik boyadır. Mongeri’nin banka yapılarında vitraylı ya da düz olarak görülen cam tavan örtüsü, ${ }^{40}$

38 Esra Yaldız ve Özge Parlak, "Birinci Ulusal Mimarlık Dönemi Kamu Yapıları," International Social Sciences Studies Journal 4/24 (2018), 4931.

39 Bu kemer tipleri Mimar Kemalettin'in tasarladığı, Gedikpaşa Mühendis Mektebi üst kat pencere açıklıklarında, Harikzedegân Katevleri'nin üçüncü kat pencerelerinde de uygulanmıştır. Bkz. Yavuz, Imparatorluktan Cumhuriyete Mimar Kemalettin 1870-1927, 118.

40 Mongeri’nin uyguladığı cam tavan örüntüsü örnekleri için bkz. Ankara İş Bankası Genel Müdürlük Binası, Ziraat Bankası Kütahya Şubesi vb. 
müşteri holünün büyük bölümünün üzerinde birinci katta çalışma mekânlarının olma$\mathrm{S1}^{41}$ ve 2013 tadilat projesinde birinci kattaki yürünebilen terasın zeminindeki "dökme mozaik korunacak" ifadesi, bu yapıda cam tavan örtüsünü yapılmadığına işaret etmektedir.

Zemin katta doğal ışı̆̆ın girmesini sağlayan kuzeybatı cephesindeki altı adet pencere diğer pencerelerden yüksek tutulmuştur. Aydınlatma, kemerlerin arasındaki bölümleri ortalayacak biçimde birer adet sarkıt aydınlatma ve sütunlarda aplikler ile sağlanmıştır (G.11).

a.

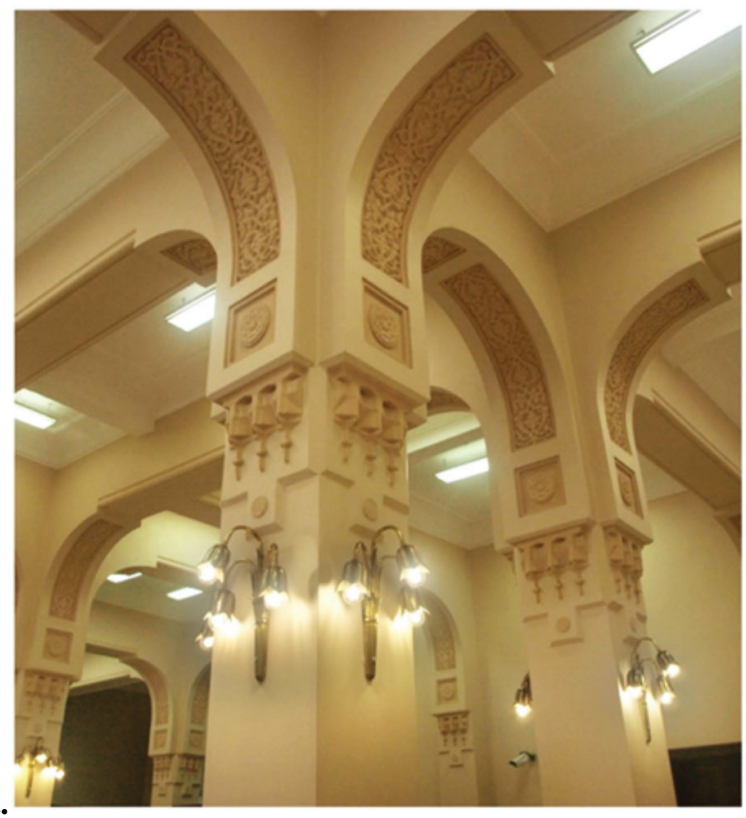

b.

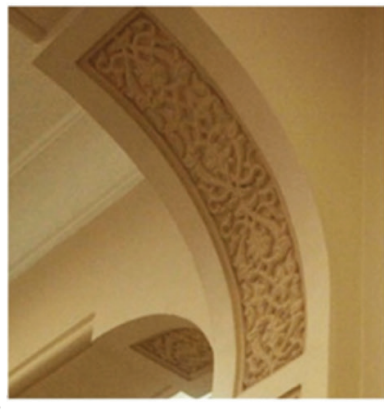

C.

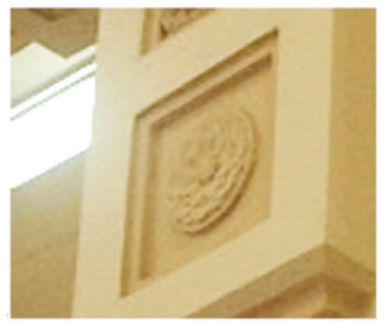

G. 12a. Eskişehir Ziraat Bankası Zemin Kat Kemer ve Mukarnaslı Sütun Başlığı. 12b. Kemer Altı Bezeme Ayrıntı. 12c. Gülçe Motifi Ayrıntı (Rabia Temel, 2018).

Binanın yapıldığı döneme ait herhangi bir veri bulunmadığından, 1926 yılında Mongeri tarafindan tasarlanan Ankara Osmanlı Bankası'na ait kaynaklar doğrultusunda iki yapının aynı dönem özelliklerini göstermesinden ve iç oda kapılarının ceviz kaplamadan yapılmasından yola çıkarak servis holünün ortasında konumlandırılan mobilyaların ceviz malzemeli ve biçimsel olarak klasik elemanlar barındırdığı düşünülmektedir (G.13). 

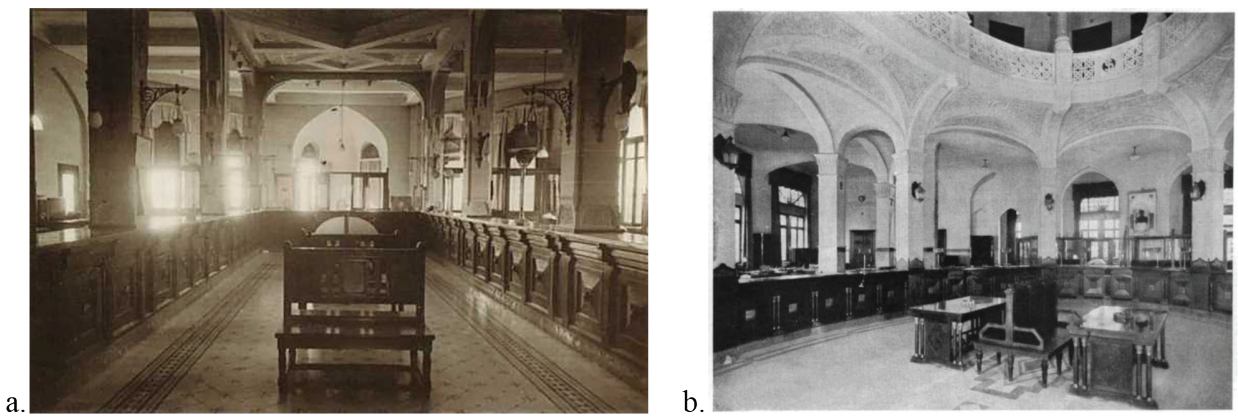

G. 13a. Ankara Osmanlı Bankası Merkez Şubesi (Mongeri, 1926 ) Zemin Kat Mobilya. "Osmanlı Bankası Şube Binaları”, http://www.mimdap.org/?p=21124z; 13b. Ankara İş Bankası Genel Müdürlük Binası (Mongeri, 1929), Zemin Kat Mobilya Mongeri, "Nuova Sede Centrale della "Banque d'Affaires" di Angora" Rassegna di Architettura, 12 (1930), 449.

Binanın strüktürü taş temel üzerine tuğla ile oluşturulmuştur. İç mekân incelemesinde yapının tadilat öncesi hâlini gösteren tarihi bilinmeyen siyah beyaz bir fotoğraftan (G.19) yararlanıldığından mekândaki malzemeler ayırt edilememiştir. Yapının köşesindeki girişte merdivenler mermerdir. Giriş holünden müşteri holüne açılan iki sabit kanat ve bir çift kanatlı kapıdan oluşan ahşap iskeletli cam kapı sistemi bulunmaktadır. Oda kapıları, pencere doğramaları ve parapetler cevizden yapılmıştır.

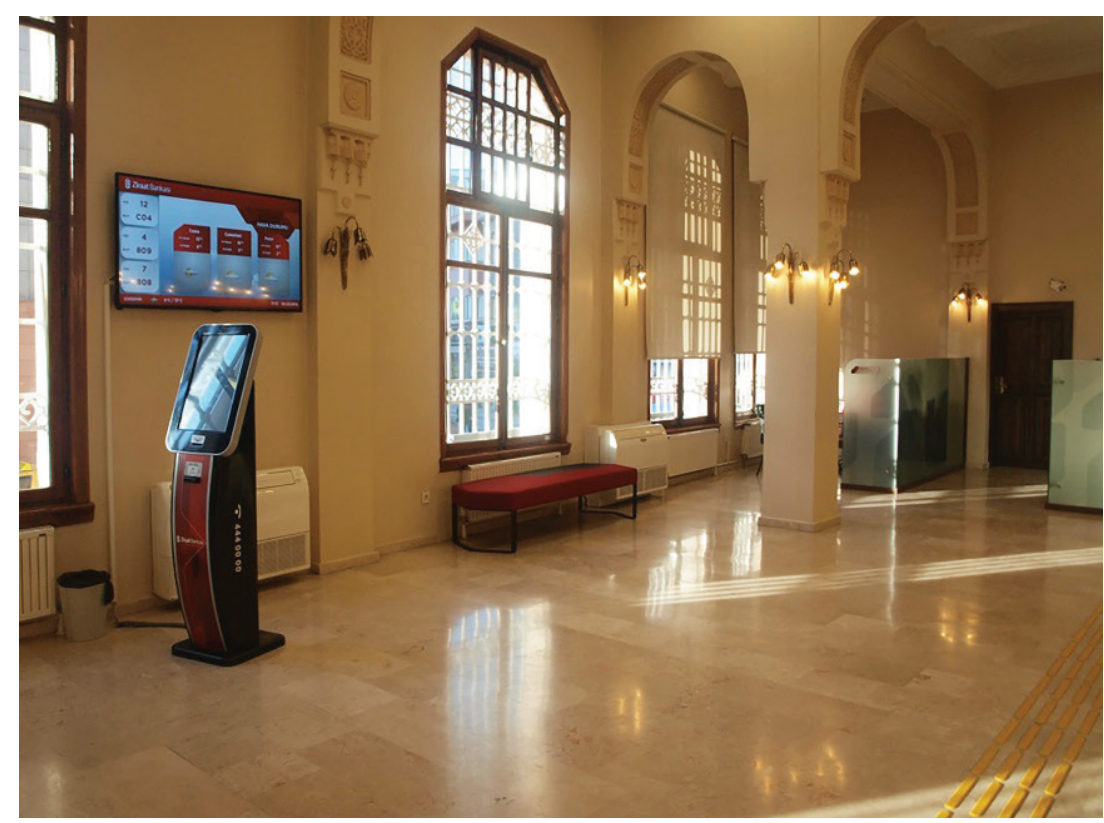

G. 14. Eskişehir Ziraat Bankası Zemin Kat Müşteri Holü (Rabia Temel, 2018).

Zeminde günümüzde banka hizmet bölümleri mermer döşeme, personel soyunma odaları ve tuvaletler seramiktir. Merdivenler mermer döşeme, korkuluklar demir, küpeşteler ceviz malzemelidir. Günümüzde ısınma sistemi kalorifer ile sağlanmaktadır. 


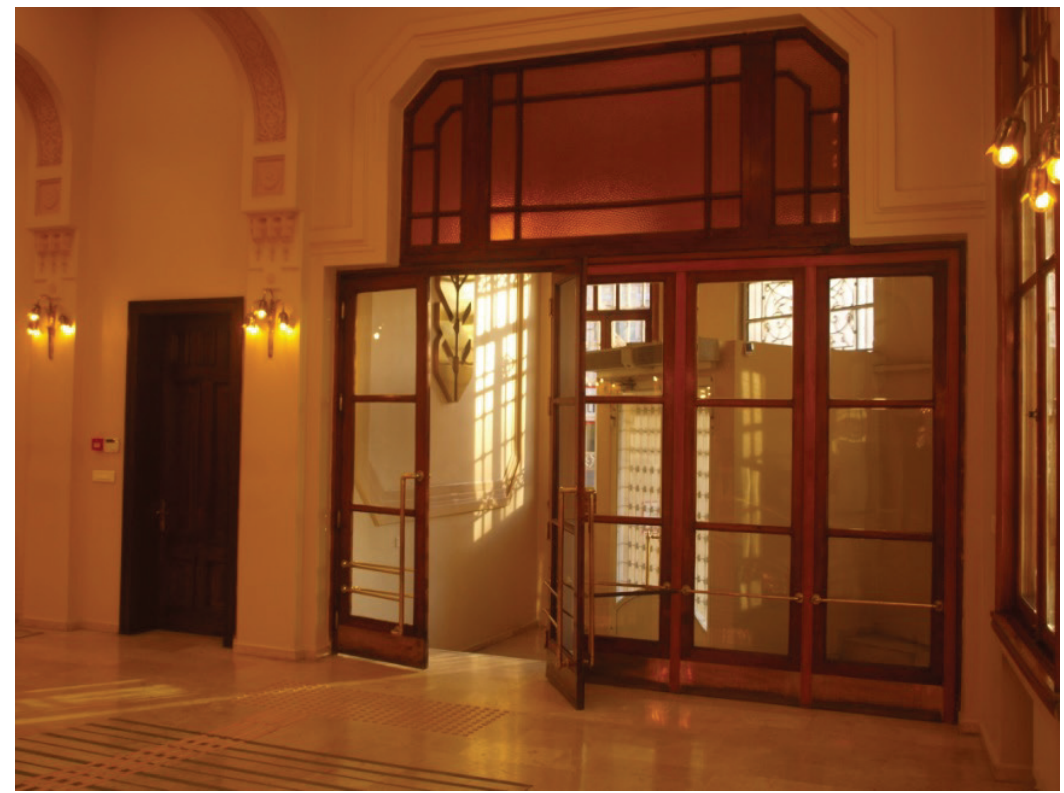

G. 15. Eskişehir Ziraat Bankası Zemin Kat İç Kapı (Rabia Temel, 2018).

\section{Ziraat Bankası Eskişehir Şube Binası Restitüsyon Araştırması}

Ziraat Bankası Eskişehir Şube Binası'nın restitüsyon araştırması, Eskişehir Kültür Varlıklarını Koruma Bölge Kurulu Müdürlüğü’nden alınan kurul karar belgeleri, Ziraat Bankası Arşivi'nden alınan proje çizimleri, Giulio Mongeri'nin banka tasarımları ile ilgili kaynaklar, dış cephe ve müşteri holü iç mekân fotoğrafları incelenerek hazırlanmıştır. Araştırma kapsamında, üç katlı yapının bankanın güvenliği gereği yalnızca zemin kat müşteri holünde iç mekân incelemesi yapılabilmiştir.

1978'de Ziraat Bankası Müdürlüğü, yapının bankanın servis ihtiyaçlarına yetersiz gelmesi sebebiyle Kültür Bakanlığı Eski Eserler ve Müzeler Genel Müdürlüğü’ne eski binanın yıkılarak yedi katlı yeni bir banka binası inşa edilmesini talep etmiştir. ${ }^{42}$ T.C. Kültür Bakanlığ 1 Gayrimenkul Eski Eserler ve Anıtlar Yüksek Kurulu Başkanlığı' nın yaptığ değerlendirmeler sonucunda 1710 ve 5805 sayılı yasalar doğrultusunda yapı hakkında 1930 yılı öncesine ait Cumhuriyet Dönemi Yapısı Ünvanı ve Eski Eser Tescili kararı alınmıştır. Ziraat Bankası, Eski Eserler ve Anıtlar Yüksek Kurulu tarafından 1979'da tescillenmiştir. ${ }^{43}$ Konya Kültür ve Tabiat Varlıklarını Koruma Kurulu, 1988 'de yapının tescil kaydının devamına karar vermiştir. ${ }^{44} 2005$ yılında ise Eskişehir

42 T.C. Kültür Bakanlığı Eski Eserler ve Müzeler Genel Müdürlüğ̈̈’ nün 10 Ağustos 1978 gün ve Müze 02.2 .750 .2 (26) sayllı yazısı.

43 T.C. Kültür Bakanlığı Gayrimenkul Eski Eserler ve Anıtlar Yüksek Kurulu Başkanlığı’nın 22 Eylül 1979 gün, A-1892 sayılı kararı.

44 T.C. Kültür Bakanlığı Konya Kültür ve Tabiat Varlıklarını Koruma Kurulu’nun 27 Haziran 1988 gün, 168 sayılı kararı. 
Kültür ve Tabiat Varlıklarını Koruma Bölge Kurulu, yapıyı Korunması Gerekli Taşınmaz Kültür Varlığı Koruma Grubu I (bir) kategorisine almıştır. ${ }^{45}$

1930’daki faaliyete başlamasından, günümüze teknolojik gelişmeler, doğal etkenler, zamana bağlı yıpranmalar nedeniyle yapının içinde ve dışında birtakım değişiklikler yapılmıştır. Bu tadilat, yenileme ve onarım işlemleri, bu bölümde kültürel miras yönetimi kapsamında incelenmiştir.

Tarihi çevrede, kentteki gelişmeler ile eklenen yapılar, banka binasının bitişiğine kadar gelmiştir. Şehir planlamasındaki yenilikler ve gelişmelere paralel olarak eklenen yeni yol ve kaldırımlar bölgedeki zemin kotunun yükselmesine neden olmuştur. Yapının çevresinin kotunun yükselmesi, kaldırımın bodrum kat pencere seviyesini geçmesine neden olmuştur (G. 16). İki Eylül Caddesi'nden 2000'li yıllar itibariyle tramvay yolunun geçmesi ile güneybatı cephesi önündeki serbest alan azalmıştır. Çevredeki büyük ve modern yapılaşma, bölgenin tarihi kimliğinin önüne geçerek binanın fark edilebilirliğini azaltmıştır.

a.
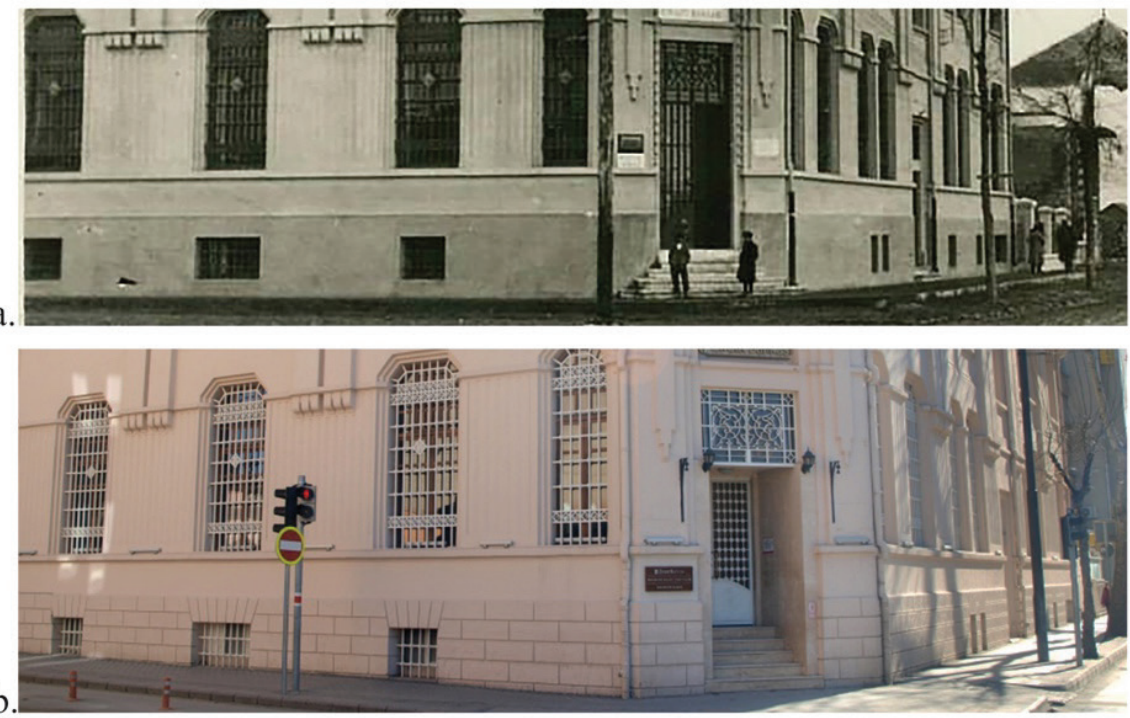

G. 16a. 1930'lu Yıllarda Yapının Kaldırım ile İlişkisi (ETBA) 16b. Günümüzde Yapının Kaldırım ile İlişkisi (Rabia Temel, 2018).

Yapının ön cephesi, köşe giriş aksının iki tarafındaki kuzeybatı ve güneybatı cepheleridir. Kıbrıs Şehitleri Caddesi'ne bakan cephe yanındaki bina ile bitişiktir. İki Eylül Caddesi'ne bakan güneybatı cephesinin devamında otopark girişi bulunmaktadır.

Cephedeki değişimler incelendiğinde, su basmanı seviyesinin 1998'deki fotoğrafında kırmızı renge boyandığı görülmektedir (G.17b). Su basmanı bölümündeki kırmızı

45 T.C. Kültür ve Turizm Bakanlığı Eskişehir Kültür ve Tabiat Varlıklarını Koruma Bölge Kurulu’nun 01 Nisan 2005 gün, 296 sayılı kararı. 
boya, 2006 y1lında binanın mevcut rengine değiştirilerek bina tek renk boyanmıştır. ${ }^{46}$ 1930'lu yıllardaki fotoğraflar incelendiğinde su basmanı seviyesinde taş dokusunun sıvayla kapatıldığı düşünülmektedir. Günümüzde su basmanı seviyesinde taraklı mozaik fugalı sıva ve bodrum pencereleri üzerine kemer görünümü uygulanmıştır. ${ }^{47} \mathrm{Bu}$ uygulamanın yapının dönemsel biçimlendirme özelliklerinde görüldüğü için yapıldığ1 düşünülmektedir.(G.17c) Güneybatı cephesindeki kapının 2013 tadilat projesinde mevcut hâlinin korunduğu ancak ilerleyen yıllarda değiştiği görülmüştür.

Yapının köşesinde yer alan giriş cephesinde zaman içerisinde pek çok kez değişiklik meydana gelmiştir. Kaldırım kotundan yüksek olan girişteki cepheden dışarı taşarak büyüyen beş basamak, ilerleyen y1llarda içeri çekilmiştir. 1998 y1lında çekilmiş fotoğraflarda giriş holündeki alan küçültülerek basamakların bu bölümün içerisine alındığı görülmektedir (G. 17). Giriş kapısı basamaklar ile aynı oranda holün içine çekilmiştir. Bu müdahaleler, Birinci Ulusal Mimarlığın dönemsel özelliklerinden olan giriş cephesindeki anıtsal mimari etkisini azaltan bir sonuç doğurmuştur. Giriş cephesindeki mevcut demir kapı, yıllar içerisinde farklı modellerle değiştirilmiştir. Yenilenen giriş kapıları biçimsel yönden farklılık gösterirken, malzeme ferforjeli camlı demir kapı olarak sürdürülmüştür. Yapının inşa edildiği tarihlerde çekilen fotoğraflar düşük çözünürlükte olduğundan giriş kapısındaki detay çizimleri 2000 sonrası ve günümüzdeki durum için yapılmıştır. 1930’lu yıllarda çekildiği bilinen fotoğraflar incelendiğinde kapının üstünde yer alan pencere ve ferforjenin orijinal hâlinin korunmuş olduğu görülmektedir.

46 T.C. Kültür ve Turizm Bakanlığg Eskişehir Kültür ve Tabiat Varlıklarını Koruma Bölge Kurulu'nun 18.03.2006 gün 1073 sayılı kararı.

47 ZBA. Tadilat Projesi'ndeki notlar doğrultusunda yazılmıştır. (2013). 

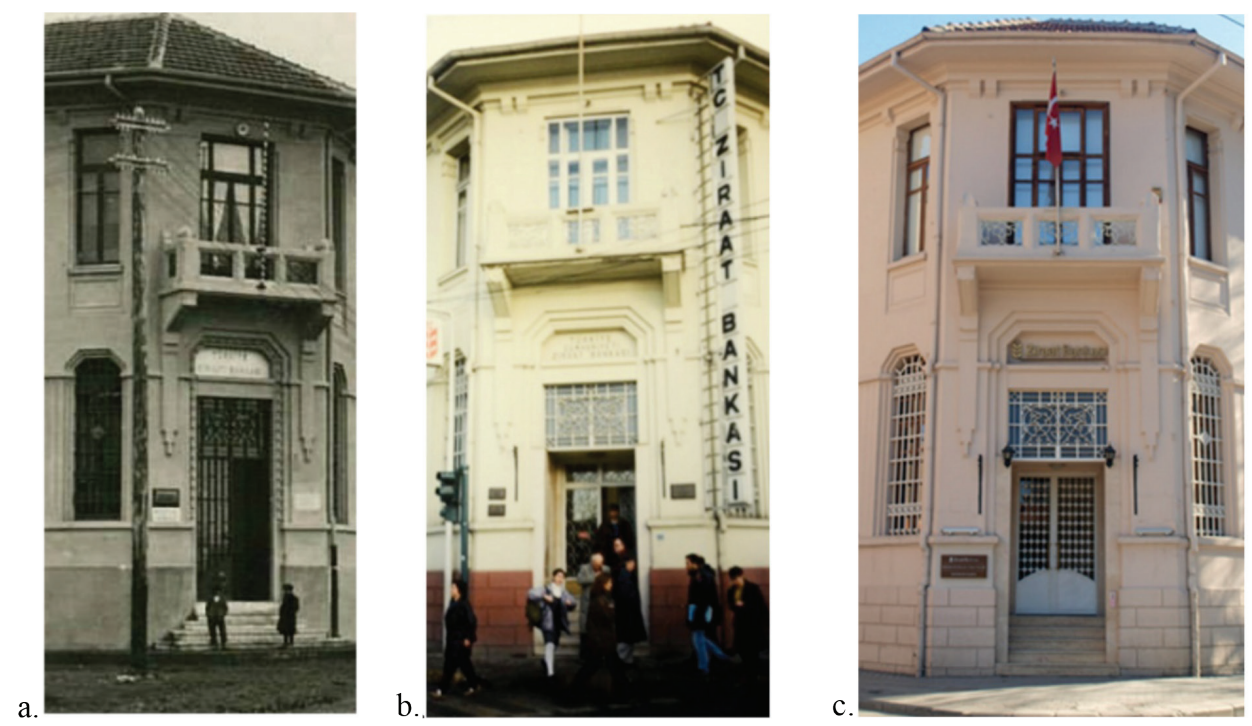

G. 17a. 1930'lu y1llarda Eskişehir Ziraat Bankası Giriş Cephesi (ETBA); 17b. Eskişehir Ziraat Bankası Giriş Cephesi (T.C. Kültür ve Turizm Bakanlığı Eskişehir Kültür Varlıkları Koruma Bölge Kurulu Müdürlüğü (EKVKBKM.), 1998) 17c. Eskişehir Ziraat Bankası Giriş Cephesi (Rabia Temel, 2018).

Giriş cephesindeki bu değişimler, yapının korunması gereken bütüncül değeri$\operatorname{nin}^{48}$ azalmasına neden olmuştur. Kapının birçok kez değiştirilmesi eski eser etkisini azaltmaktadır. Kapı açıklığı üç kademeli olarak kapının etrafını çerçevelemektedir. Etrafındaki bordür içinde bir bezeme algılanmaktadır. Yapının 1998 ve 2018 tarihli fotoğraflarında bu bezemenin kaldırıldığı görülmektedir (G.17a, 17b, 17c). Bezemelerin günümüze ulaşmamış olması yapının tarihi özelliğinin anlaşılmasını zorlaştırmaktadır.

Saçak altındaki kornişte bir sıra belirlenemeyen bezeme görülmektedir (G. 3). Müşteri holündeki künyede, saçak altında yumurta dizileri bulunduğu ifade edilmiştir. İlerleyen yıllara ait fotoğraflarda ve cephe çizimlerinde bu bezemelerin kaldırıldığ görülmüştür. Yapıda kullanılan tasarım anlayışının ifade eden özelliklerden biri olan bezemelerin kaldırılması yapının korunması gereken estetik ve sanatsal değerini ${ }^{49}$ azaltmaktadır.

48 "ICOMOS Türkiye Mimari Mirası Koruma Bildirgesi 2013” III.2. Koruma Değerleri. ICOMOS erişim 18 Nisan 2018, http://www.icomos.org.tr/Dosyalar/ICOMOSTR_tr0784192001542192602.pdf

49 “ICOMOS Türkiye Avrupa Mimari Mirası Koruma Bildirgesi 2013” III.2. Koruma Değerleri. 


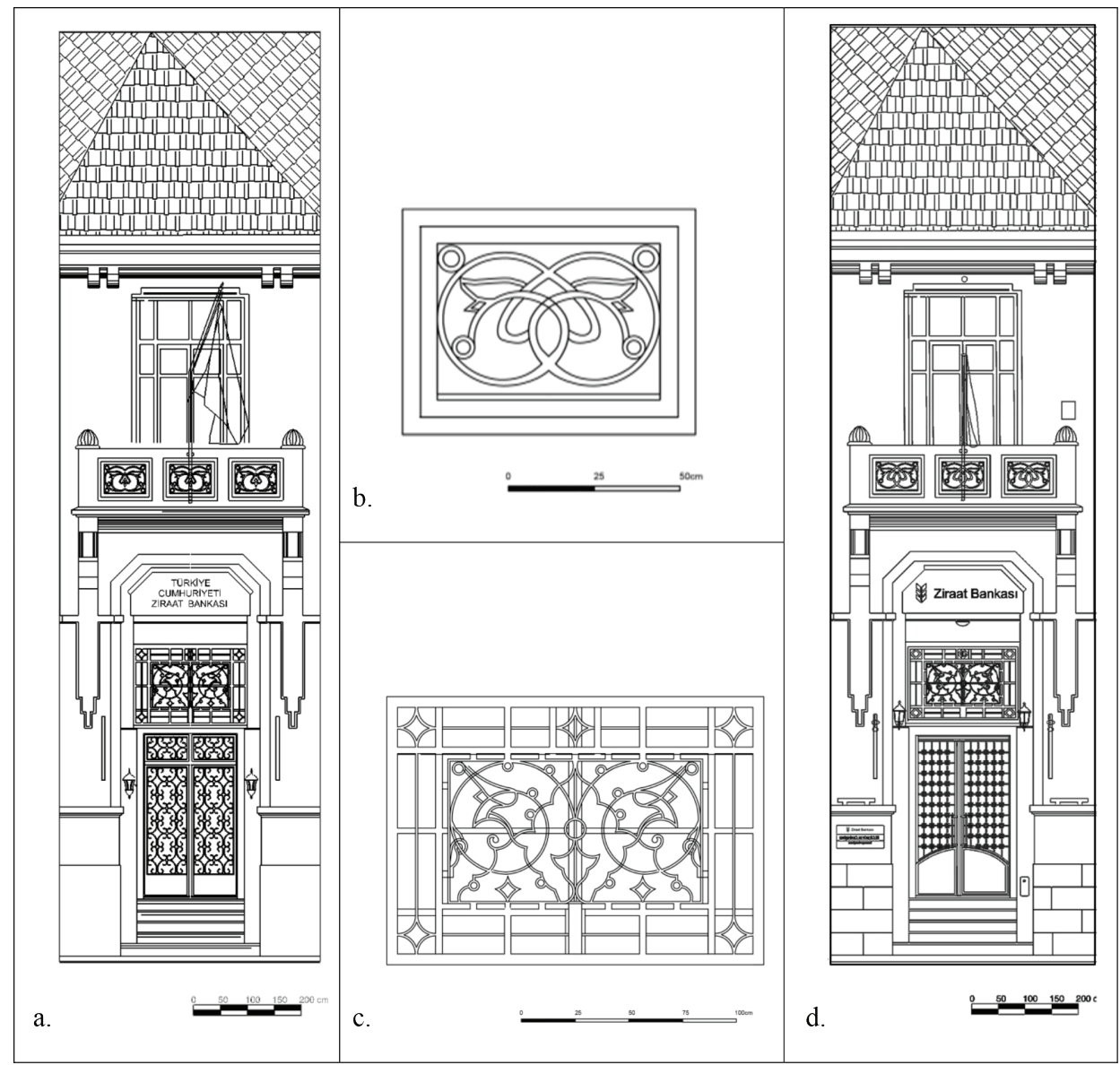

G. 18a. Giriş Cephe Çizimi (ZBA., Çizim: Y. Mimar Reşat Toklu, 2013); 18b. Balkon Korkuluk Ferforje Ayrıntı (ZBA., Çizim: Y. Mimar Reşat Toklu, 2013'den İşlenmiş Çizim Rabia Temel); 18c. Giriş Kapısı Üzeri Açıklık Ferforje Ayrıntı (Reşat Toklu, 2013); 18d. Giriş Cephe Çizimi (İşlenmiş Çizim Rabia Temel).

Giriş cephesindeki değişimlerden biri de banka tabelasıdır. Giriş kapısının bulunduğu kemerin altındaki alınlıkta tabela için yer ayrılmıştır. 1930'lu yıllara ait fotoğrafta burada beyaz fon üzerine Türkiye Ziraat Bankası yazılmıştır. 2013 tarihli çizimde tabelada Türkiye Cumhuriyeti Ziraat Bankası yazarken günümüzde yalnızca Ziraat Bankası kullanıldığı görülmüştür. Kapının yan tarafında levha üzerindeki yazılar eklenmiştir. 2005'te Ziraat Bankası Müdürlüğü yapıya 1şıklı reklam panosu eklenmesi talebinde bulunmuş olsa da T.C. Kültür ve Turizm Bakanlığı Eskişehir Kültür Varlıklarını Koruma Bölge Kurulu Müdürlüğü tarafından Korunması Gerekli Taşınmaz Kültür Varlığı yapısına uyum sağlamayacağından bu talep reddedilerek cephe bütünlüğü korunmuştur. ${ }^{50} 1998$ yılına ait fotoğrafta cepheye uzunlamasına yerleştirilen

50 T.C. Kültür ve Turizm Bakanlığı Eskişehir Kültür ve Tabiat Varlıklarını Koruma Bölge Kurulu 22.10.2005 gün 703 sayılı kararı. 
tabela kaldırılarak banka isminin pirinç harflerle yazılması uygun görülmüştür (G.17b, G. 17c). 2005 yılında çekilen fotoğraflarda ana giriş kapısı yan cephelerinde birçok levha asılı olduğu görülmektedir. Günümüzde bina numarası, banka ismi vb. bilgilerin yazdığı levhalar kaldırılarak tek parçada toplanmıştır (G.17c).

Zamana bağlı yıpranmaların giderilmesi amacıyla düzenli olarak çatı kiremitleri ve yağmur oluklarında yenilemeler yapılmıştır. 2007 yılında baca onarımı ve çatı aktarımı yapılmış, tadilatın özgün doku bozulmadan yapıldığı tespit edilmiştir. ${ }^{51}$ Çatıdaki yağmur olukları çinko malzemeli yeni oluklarla değiştirilmiştir. ${ }^{52}$ Sac malzemeli iniş boruları gerekli onarımlar yapılarak korunmuştur. ${ }^{53}$

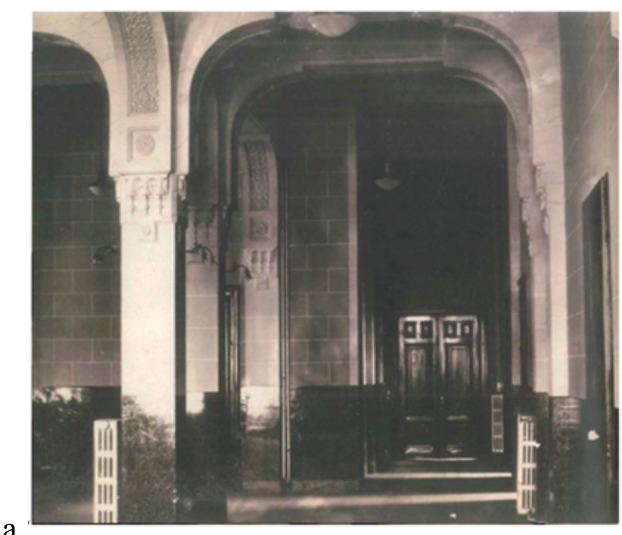

G. 19a. Ziraat Bankası Müșteri Holünden Z13 koridor görünümü (Fotoğraf tarihi bilinmiyor.) (Uğur Tanyeli, Mimarlı̆̆ın Aktörleri Türkiye 1900-2000, 380). 19b. Ziraat Bankası Müşteri Holünden Z13 koridor görünümü (Rabia Temel, 2018).

2007 yılında ilgili kurumdan alınan izinle iç mekânda badana yapılmıştır. İç mekândaki sütun ve kemerlerdeki kabartmalar duvar renginin bir ton koyusuna boyanarak bu bölümlere vurgu yapılmak istenmiştir. ${ }^{54}$

Dönemin kamusal yapılarında anıtsal mimari, iç mekân tavan yüksekliği ve geniş müşteri alanı ile yansıtılmıştır. Mongeri’nin “Ankara Osmanlı Bankası”, “Ankara İş Bankası (G. 13)" ve "İş Bankası Galata Şubesi" 55 müşteri holünde sütunlar arasına vezne bankolarının yerleştirildiği görülmüsstür. Bu örneklerden yola çıkarak Eskişehir'deki yapının ilk hâlinde de vezne bankolarının holdeki sütunlar arasına yerleşti-

51 T.C. Kültür ve Turizm Bakanlığı Eskişehir Kültür ve Tabiat Varlıklarını Koruma Bölge Kurulu Müdürlüğü talebiyle oluşturulan 19 Ekim 2007 tarih 5769 sayılı Uygulama Sonrası Tespit Tutanağı

52 ZBA. Tadilat Projesi’ndeki notlar doğrultusunda yazılmıştır. (2013).

53 ZBA. Tadilat Projesi’ndeki notlar doğrultusunda yazılmıştır. (2013).

54 T.C. Kültür ve Turizm Bakanlığı Eskişehir Kültür ve Tabiat Varlıklarını Koruma Müdürlüğü 08 Ağustos 2007 gün B.16.0KTV.4.26.00.00-720-26.00/70-1919 sayılı kararı.

55 Orhan Koçak, Atatürk'ün Bankası: Türkiye Işs Bankası (İstanbul: Türkiye İş Bankası Yayınları, 2001), 87, 100 . 
rildiği düşünülmektedir. Müşteri holü (Z02) ile Z13 koridorunu birbirinden ayırmak üzere kiriş altından kap1 kasası yüksekliğine kadar alçıplak ${ }^{56}$ duvar örülmüştür ve bu iki mekân mevcut zemin kat kapılarına uygun olacak biçimde bir kapı ile birbirinden ayrılmıştır. Bu bölümlendirme yapının anıtsal etkisini azaltmaktadır (G.19).

Açık çalışma ofisi biçimde tasarlanan müşteri holünde zamanla bölümlendirme gereksinimi doğmuştur. Müdür yardımcısı ve operatörlerin çalıştığı Z03 bölümü, bireysel hizmetlerin bulunduğu Z06 ve danışmanın yer aldığ $\mathrm{Z} 05$ bölümleri lamine cam bölmeler ile sınırlandırılmıştır. Yarı geçirgen baskılı lamine cam bölmeler, modern malzeme ve tasarım anlayışıyla yapılmıştır. Holün kuzeyinde Z05 bölümündeki bölmelendirmede proje ve uygulama arasında farkl1l1k görülmüştür. Uygulama sırasında Z14 koridoru kapısının önünde geçiş alanı bırakılmıştır (G. 10, G. 14, G. 20).

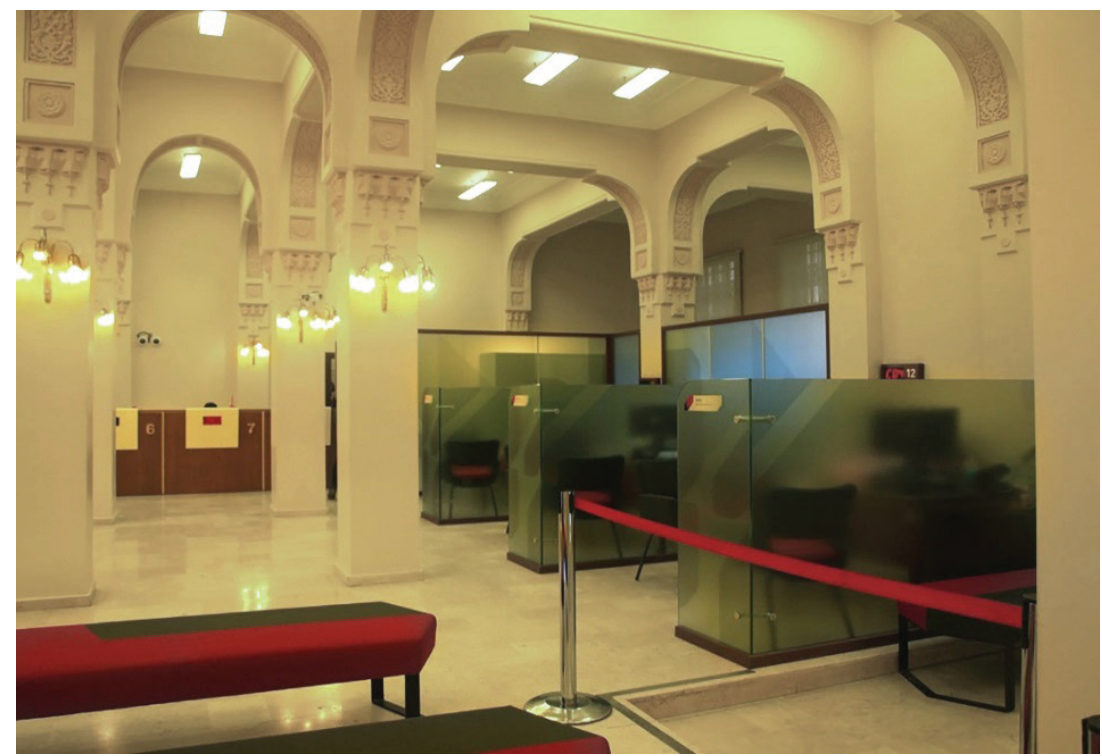

G. 20. Eskişehir Ziraat Bankası Zemin Kat Cam Bölmeler (Rabia Temel, 2018).

1997 yılında Banka Müdürlüğü tarafından 1sınma problemi nedeniyle doğramaların PVC malzeme ile yenilenmesi talebinde bulunulmuştur ancak Eskişehir Kültür ve Tabiat Varlıklarını Koruma Kurulu, bu talebin yapının bütüncül olma değerine uymayacağı kanaatiyle, talebi reddederek ahşap doğramaların aslına uygun olarak yenilenebileceğine karar verilmiştir. ${ }^{57} 2005$ 'te yapılan badana sırasında sonradan beyaz ile renklendirilen pencere doğramaları orijinal rengi olan ceviz rengine yeniden boyanmıştır (G.17).

56 ZBA. Tadilat Projesi’ndeki notlar doğrultusunda yazılmıştır. (2013).

57 T.C. Kültür Bakanlığı Eskişehir Kültür ve Tabiat Varlıklarını Koruma Kurulu 23 Ocak 1998 gün 468 sayılı kararı. 

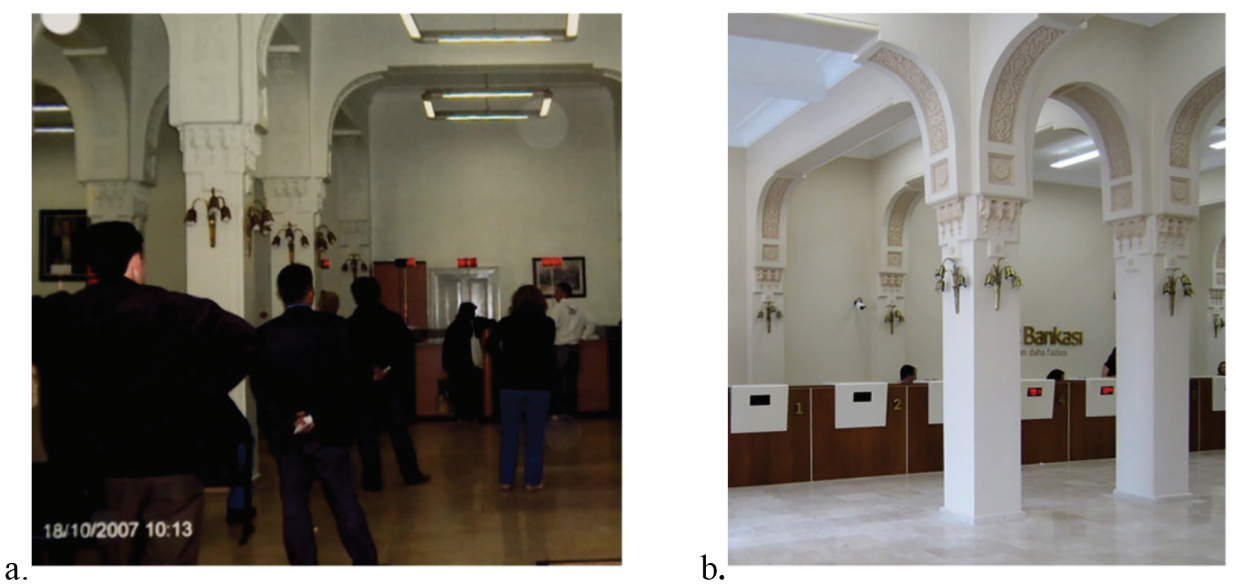

G. 21a. Servis Bankoları (EKVKBKM., 2007); 21b. Servis Bankoları (ZBA., 2014).

Mekânın genel aydınlatmasını sağlayan elemanlar yeni teknoloji armatürlerle değiştirilmiştir. Mekânın aydınlık derecesi bu sayede arttırılmıştır. Tanyeli’nin arşivinde yer alan iç mekân fotoğraflarındaki sütunlarda bulunan apliklerin değiştiği gözlemlenmiştir. Tarihi bilinmeyen bu değişikliğin elektrik teknolojilerinden kaynaklandığ düşünülmektedir (G.19). Orta hol bölümünde oturma birimleri bankanın kurumsal renklerinde düzenlenmiş ve mekânın mimari karakterine zıt olarak modern mobilyalar tercih edilmiştir. Günümüzde kullanılan vezneler modern biçimde ahşap malzemelidir (G.11, G. 20). 2007'deki fotoğrafta vezne bankolarının üzerine metal taşıyıcılar yoluyla yerleştirilmiş numaratörlerin olduğu, günümüzde ise mobilyalar ile bütünleşik bir şekilde konumlandırıldığı dikkat çekmektedir (G. 21a, G. 21b).

Isıtma sistemi olarak doğalgaz teknolojisine geçilmesiyle petekler yenilenmiştir. Yap1, doğalgaz sisteminden önce kömür ile 1sıtılmıştır. Tanyeli'nin arşivlediği fotoğrafta o dönemde döküm kalorifer petekleri kullanıldığı görülmektedir (G. 19). 1990'lı yıllarda takılmış olan klima dış üniteleri sonradan kuzeybatı cephesinden kaldırılarak yapının arka cephesine taşınmıştır (G. 22). Klima teknolojilerinin değişmesiyle zemin katta split tipi klimalar kullanılmıştır. 

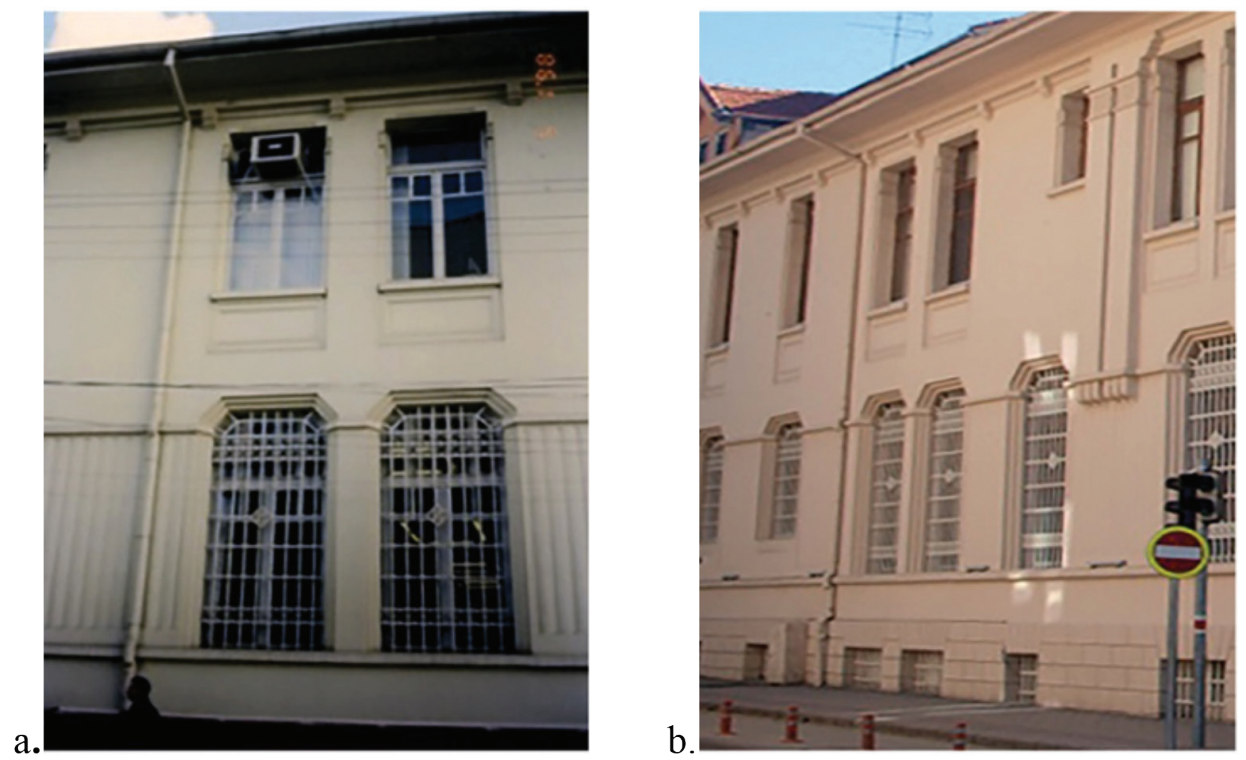

G. 22a. Ziraat Bankası Kuzeybatı Cephesi Doğrama, Klima ve Cephe Rengindeki Değişimler (EKVKBKM., 1998) 22b. Ziraat Bankası Kuzeybatı Cephesi Doğrama, Klima ve Cephe Rengindeki Değişimler (Rabia Temel, 2018).

Ziraat Bankasının yapıldığı yıllarda henüz bulunmayan ATM inşaatı için 2004 yılında izin alındığında Eskişehir Kültür Varlıklarını Koruma Bölge Kurulu Müdürlüğü tarafından ATM binasının ana binanın küçük bir kopyası niteliğinde aynı cephe rengi ve çatı görünümünde yapılması koşulu sunulmuştur. ${ }^{58}$ Artan nüfusla birlikte binanın önündeki kaldırım yetersiz kalmıştır, ön caddeden tramvay geçtiği için daralan araç yolu da yoğun bir trafiğge sahip olduğu için özellikle maaş günlerinde ATM'de sıra bekleyen kullanıcıların kaza tehlikesi yaşadığı gerekçesiyle bu bina yıkılmış, garajın iç kısmına doğru daha geride konumlandırılan yeni bir bina yapılmıştır. ${ }^{59} \mathrm{Bu}$ yeni ATM kaldırımda bir metre daha genişlik eklenmiş ve kullanım alanı saat yönünün tersinde 90 derece döndürülerek güney doğu yönünden erişilecek biçimde inşa edilmiş, ana yapıya uygunluk kaygısı gözetilmemiştir. ${ }^{60} 2005$ yılında bahçe kapısı güvenlik nedeniyle, otomatik kapı olarak yapılmıştır (G. 23). ${ }^{61}$

58 T.C. Kültür ve Turizm Bakanlığı Eskişehir Kültür ve Tabiat Varlıklarını Koruma Kurulu 08.04.2004 tarih 2707 sayılı kararı.

59 13.08.2004 tarih ve 646 sayılı Eskişehir Büyükşehir Belediyesi A.P.K. Daire Başkanlığı Yazısı.

60 T.C. Kültür ve Turizm Bakanlığı Eskişehir Kültür ve Tabiat Varlıklarını Koruma Bölge Kurulu 13.01.2005 tarih 182 sayılı kararı.

61 T.C. Kültür ve Turizm Bakanlığı Eskişehir Kültür ve Tabiat Varlıklarını Koruma Bölge Kurulu 01.04.2005 tarih 296 sayılı kararı. 


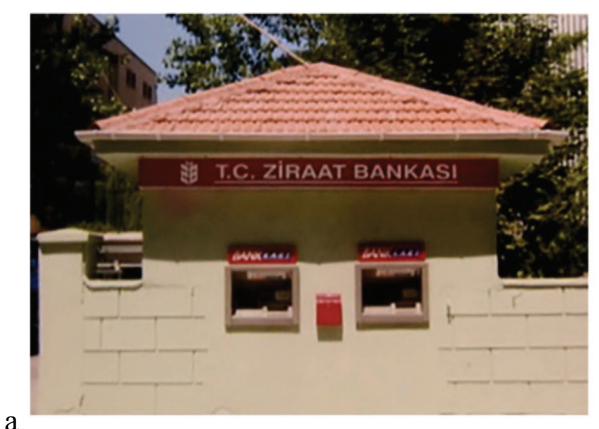

G. 23a. İlk ATM Binası (erişim Güney Batı yönünde) (EKVKBKM., 2004); 23b. Yenilenen ATM Binası (erişim Güney Doğu yönünde) (Rabia Temel, 2019).

Eskişehir Ziraat Bankası Şube Binası ilk işlevine uygun olarak kullanımını sürdürmektedir. Zaman içinde ortaya çıkan ihtiyaçların karşılanması için uygun çözümler bulunmaya çalışıldığı görülmektedir. Bu değişikliklerin yapının özgünlüğüne olumsuz yönde etki etmesi kaçınılmazdır. Eskişehir Erken Cumhuriyet döneminde kent belleğinin simge yapılarından olan Ziraat Bankası'ndaki değişimler ve etkileri sonuç bölümünde değerlendirilmiştir.

\section{Sonuç}

Ziraat Bankası Eskişehir Şube Binası Birinci Ulusal Mimarlık Akımı özelliklerinde tasarlanmıştır. Eskişehir'de yapılması planlanan Ziraat Bankası Eskişehir Şubesi için 1906-1907 yıllarında arazi tahsis edilmiştir. 1928' de başlayan inşaatın açılışı Cumhuriyet'in yedinci yılında 29 Ekim 1930 tarihinde yapılmıştır. Dolayısıyla kent belleğinde Cumhuriyet'in kent kimliği ile özdeşleşmiş bir yapıdır.

Yapının yerleştirildiği parselden dolayı yalnızca köşedeki giriş cephesinde simetri uygulanmıştır. Cadde ve sokağa bakan ön cepheler, dönem özelliklerine uygun olarak arka cephelere kıyasla zengin bezemeye sahiptir. Cephelerin silme ve plasterlerle yatay ve dikey bölümlendirilmesi, pencere biçimlerinin katlar arasında farklılık göstermesi ve dikey öğelerle cephede ritmik bir düzen oluşturulması, bu akımında Rönesans'tan gelen etkilerin uyarlanmasına örnektir. ${ }^{62}$ Mongeri, yapıda katları birbirinden ayıran yatay silmeleri bu dönem özelliklerinde görüldüğü gibi iki kat arasında konumlandırmak yerine zemin kat pencere kemerlerinin bitiş hizasına kurgulamıştır. 1. katta pencerenin üzerini plasterden uzanarak dolanan bezeme, müşteri holünde kullanılan ve dönemde nadir görülen genişletilmiş Bursa tipi kemere göndermedir. İç mekânda kullanılan ve 14.-15. yüzyıl Osmanlı dönemi Bursa mimarisinin özelliğini yansıtan bu kemer tipi, Selçuklu ve Osmanlı mimarisinin en belirleyici unsurlarından olan mukarnas başlıklı sütunlarla dönemi vurgulamaktadır. Kemer altlarındaki 
kabartma bitkisel motifler ve altlarında konumlandırılmış gülce rozetler aynı şekilde dönemin özelliğidir. Dış cephe ve iç mekânda dikey konumlandırılan bezemelerin kademeli olarak sonlandırılması da bir dil birliği oluşturmaktadır.

Yapının mimari dili, bu dönemde Ankara'da inşa edilen banka yapıları ile kıyaslandığında, oldukça sadedir. Eskişehir şubesinde, vitray, çini ve kalem işi gibi öğeler görülmemektedir. Yapının özgün hâlinde bu öğelerin uygulanmasına ilişkin belge tespit edilmemekle birlikte, yapıda sade bir tasarım anlayışı kullanıldığı varsayılabilir. Anadolu'daki Ziraat Bankası şube yapıları, Selçuklu ve Osmanlı döneminden dekoratif öğeler, pencere biçimleri, giriş cephesini vurgulayan mimari unsurlar gibi ortak dönemsel özellikler içermektedir. Adana ve Eskişehir şubeleri genel hatlarıyla benzerlik gösterse de mimari unsurlar detaylı incelendiğinde farklılıklar dikkat çekmektedir. Eskişehir, Adana ve Kütahya şubelerinde aynı köşe kemerli pencere biçimi kullanılmıştır. Yapıların mekân organizasyonuna bakıldığında, 3 katlı olduğu, bu katların bodrum arşiv ve depo, giriş kat banka hizmetleri, 1. katın banka çalışanları için lojman olarak aynı işlevlere yönelik düzenlendiği görülmüştür. Tek girişi olan müşteri holü ve etrafına yerleştirilen odalar bu yapılardaki ortak plan özelliklerini gösterirken, Adana, Aydın ve Manisa şubelerinde müşteri holünün ortasındaki cam tavan örtüsünün Eskișehir'de uygulanmaması yapılar arasındaki farklılıklardandır. ${ }^{63}$ Mongeri’nin bazı banka yapılarında ve Eskişehir'de uyguladığı geniş aynalı Bursa kemerleri, bu dönemde nadir olarak kullanılan kemer türlerine girmektedir (G. 12) ${ }^{64}$ Birinci Ulusal Mimarlık akımında cephe düzenlemeleri için oluşturulmuş kurallar bu yapılardaki ortak öğelerin kullanımını açıklamaktadır. Mongeri'nin mimari çalışmalarını içeren üç üslubu doğrultusunda, "İzmir Banca Commerciale" ile "Eskişehir Ziraat Bankası" inşaatı aynı döneme denk gelmesine rağmen yapılardan birinin yabancı, diğerinin yerli bir firma için yapılmış olması nedeniyle bu yapılarda farklı mimari öğeler kullanılmıştır.

Mongeri’nin Eskişehir'de Birinci Ulusal Mimarlık üslubundaki örneği olan yapı için, mevcut tek proje 2013 tadilat projesidir. Ancak, cephesinde ve zemin kat müşteri holünde, fotoğraflar, müdahalelere yönelik ilgili kurul kararları ve belgeler doğrultusunda farklı yıllarda da bakım, onarım ve tadilat yapıldığı anlaşılmıştır. Kültürel mirasın koruma ilkeleri açısından değerlendirildiğinde bu müdahalelerin, tarihî bütünlüğü ve mimari özgünlüğünü korumaya çalışarak yapıldığı görülmüştür. Yapının günümüzdeki hâlinde su basman kotuna kadar olan yüzeylerde yapay kesme taş görünümü uygulanmıştır. Cephede giriş kapısı ve tabela birkaç kez değişmiştir. Saçak altındaki kornişte yer alan yumurta dizileri, giriş kapısının çevresindeki bezemeler yapının ilk hâlinde bulunurken, ilerleyen yıllarda bu bezemelerin kaldırıldığı görülmüştür. Eldeki belgeler doğrultusunda bu değişikliklerin 1979'daki tescilinden önce yapıldığg 1

63 Duygu Saban, “Giulio Mongeri’nin Anadolu'daki İzleri-Ziraat Bankası Şube Binaları,” 74, 76.

64 Yavuz, Imparatorluktan Cumhuriyete Mimar Kemalettin 1870-1927, 119. 
düşünülmektedir. Kapı, önündeki basamaklar yapı kütlesinin içine alındığından yer değiştirmiş ve farklı yıllarda model değişikliğine uğramıştır. Zaman içinde yapıdaki yıpranmalar nedeniyle bakım ve onarım yapılmıştır.

Müşteri holünde, tescil tarihinden itibaren uygulanan değişiklikler, verilerden izlenebildiği kadarıyla incelendiğinde, dönem özelliklerinin en yoğun şekilde yansıtıldığı sütunların, sütun başlıklarındaki mukarnasların ve diğer motiflerin, kemerlerin, kemer altı bezemelerinin özenle korunduğu görülmüsstür. Gelişen teknoloji ve değişen gereksinimlerin karşılanması için yapılan eklemelerde yapının bütünlüğünün bozulmamas1na dikkat edilmiştir. Yeni mekânsal gereksinimler için yapının özgün tasarım algısını bozmamak için şeffaf malzemelerle bölmelendirme yapılmıştır. Vezne bankosu, bekleme üniteleri gibi donatı elemanları çağdaş tasarım ürünlerdir. Bekleme ünitelerinde kullanılan renklerin baskın bir rol oynamasına karşın yapının ilk hâlini anımsatmaya çalışan taklit ürünler yerine çağdaş tasarımların tercih edilmesi yapının mimari kimliğini oluşturan özelliklerin ayırt edilebilmesini sağlamaktadır. Bu bölümde bir dönem duvarda iki farklı malzeme uygulandığı, bu malzemelerin zamanla değiştiği tespit edilmiştir (G. 19). Isınma ve aydınlatma sistemlerinde yenilemeler yapılmıştır. Bankanın güvenlik önlemleri gereği mekân incelemesinin yapılabildiği tek bölüm olan müşteri hölü yapının dönemsel özelliklerini en yoğun biçimde yansıtan yerdir.

Yaklaşık doksan yıldır "banka" işlevinin sürdüren yapıda Birinci Ulusal Mimarlık akımı özelliklerinin tam olmasa da korunduğu tespit edilmiştir. Yapının etrafındaki yoğun yapılaşma nedeniyle mimari ve kültür miras olarak algılanması gittikçe zorlaşmaktadır. Bu çalışmanın, yapının gerek korunması gerekse kent kimliği içindeki değerinin anlaşılarak farkındalık yaratabilmesi ümit edilmektedir.

Hakem Değerlendirmesi: Dış bağımsız.

Çıkar Çatışması: Yazarlar çıkar çatışması bildirmemiştir.

Finansal Destek: Yazarlar bu çalışma için finansal destek almadığını beyan etmiştir.

Teşekkür: Araştırma kapsamında arşivlerinden yararlanılmasına izin veren, Eskişehir Tepebaşı Belediyesi’ne, T.C. Kültür ve Turizm Bakanlığı Eskişehir Kültür Varlıklarını Koruma Bölge Kurulu Müdürlügü’ne, Ziraat Bankası İnşaat Yönetimi Bölüm Başkanlığı'na, Ziraat Bankası Eskişehir Şube Müdürlüğü’ne, Yüksek Mimar Reşat Toklu’ya, yapının eski fotoğraflarını günümüze ulaştıran Ahmet Atuk'a teşekkürlerimizi sunarız.

Peer-review: Externally peer-reviewed.

Conflict of Interest: The authors have no conflict of interest to declare.

Grant Support: The authors declared that this study has received no financial support.

Acknowledgement: We would like to thank to Eskişehir Tepebaşı Municipality, which allows the use of archives within the scope of the research, to the Ministry of Culture and Tourism Eskişehir Cultural Assets Protection Regional Board Directorate, to Ziraat Bank Construction Management Department, to Ziraat Bank Eskişehir Branch Directorate, to Architect Reşat Toklu and Ahmet Atuk for the old photographs of the building. 


\section{Kaynakça/References}

Akpolat, M. Servet. "Fransız Kökenli Levanten Mimar Alexandre Vallaury.” Doktora Tezi, Hacettepe Üniversitesi, 1991.

Aslanoğlu, İnci. Erken Cumhuriyet Dönemi Mimarlı̆̆ 1923-1938. İstanbul: Bilge Kültür Sanat Yayınevi, 2010.

Batur, Afife. M. Vedat Tek: Kimliğin İzinde Bir Mimar. İstanbul: Yapı Kredi Yayınları, 2003.

Başbakanlık Osmanlı Arşivi (BOA), Eskişehir Hükümet Konağı'nın karşısında Belediyeye ait arsadan miktar-1 kafi bir mahal ifrazıyla Ziraat Bankası ittihaz olunmak üzere daire inşası, 00016.00008.001.001, (1906-1907).

Berkant, Cenk. “İzmir'de İki İtalyan Projeci: Stefano Molli (1858-1916) ve Giulio Mongeri (18731953).” Ege Mimarlık 1 (89-90) (2015): 50-53.

Bozdoğan, Sibel. Modernizm ve Ulusun İnşası: Erken Cumhuriyet Türkiye sinde Mimari. İstanbul: Metis Yayınc1lik, 2012.

Can, Cengiz. "İstanbul'da 19. Yüzyıl Batılı ve Levanten Mimarların Yapıları ve Koruma Sorunları.” Doktora Tezi, Yıldız Teknik Üniversitesi, 1993.

Cengizkan, Ali. Modernin Saati-20. Yüzyılda Modernleşme ve Demokratikleşme Pratiğinde Mimarlar, Kamusal Mekan ve Konut Mimarlı̆̆ı. Mimarlar Derneği 1927 Yayınları. İstanbul: Boyut Yayin Grubu, 2002.

Cezar, Mustafa. Typical Commercial Buildings of the Ottoman Classical Period and the Ottoman Construction System. İstanbul: Türkiye İş Bankası Kültür Yayınları, 1983.

Çinici, Damla. Türkiye Cumhuriyeti Mimarlığının Modernleşme Sürecinde Mimar Giulio Mongeri: Bursa Çelik Palas Oteli ve Kaplıcası. Bursa: Nilüfer Belediyesi Yayınları, 2017.

Eldem, Sedad Hakkı. "Elli Yıllık Cumhuriyet Mimarlığı.” Mimarlık Dergisi 121 (11-12) (1973): 5-11.

Erten, Özlem İnay. Şişli'de bir Konak ve Mimar Giulio Mongeri/ A Mansion in Şişli and Architect Giulio Mongeri. İstanbul: Bozlu Sanat ve Yayınc1lık, 2016.

Eskişehir Tepebaşı Belediye Arşivi.

Fasoli, Vilma. "Giulio Mongeri Edoardo De Nari and the "Societâ Anonima Ottomana Costruzioni" (S.A.O.C.)," Italian Architects and Builders in the Ottoman Empire and Modern Turkey: Design Across Borders. Ed. Paolo Girardelli ve Ezio Godoli. Newcastle: Cambridge Scholars Publishing, 2017, 213-227.

Girardelli, Paolo. "Italian Architects in an Ottoman Context: Perspectives and Assessments." İstanbul Araştırmaları Yıllı̆̆gl 1. İstanbul: İstanbul Araştırmaları Enstitüsü, 2011, 101-122.

Hazar, Nurettin. T.C. Ziraat Bankası 1863-1983. Ankara: Fon Matbaası, 1986.

İlter, Şahap Sıtkı. Ziraat Bankası Dün-Bugün. Ankara: Başnur Matbaası, 1967.

Kızıldere, Selda ve Metin Sözen. “İstanbul'da Birinci Ulusal Mimarlık Dönemi Yapıları'nın Kent Bütünü İçindeki Yerinin Değerlendirilmesi.” İTÜ Dergisi/b, Sosyal Bilimler 2/1 (2005): 87-95.

Koca, Güler ve Rana Karasözen, “1945-1960 Dönemi Eskişehir Modern Kent Merkezinin Oluşumunda Öne Çıkan Yapılar.” Anadolu Üniversitesi Sosyal Bilimler Dergisi 10/3 (2010): 191-211.

Koçak, Orhan. Atatürk’ün Bankası: Türkiye İş Bankası. İstanbul: Türkiye İş Bankası Yayınları, 200.

Koylu, Zafer. “XX. Yüzyılın Başlarında Eskişehir.” Atatürk Araştırma Merkezi Dergisi 24/71 (2008): 381-412. 
Mongeri G. "Nuova Sede Centrale della "Banque d'Affaires" di Angora" Rassegna di Architettura 12 (1930): 448-451.

Saban, Duygu. “Giulio Mongeri’nin Anadolu'daki İzleri Ziraat Bankası Şube Binaları.” Mimarlık 405 (2019): 73-77.

Saban, Duygu. “Giulio Mongeri’ nin Banka Tasarım İlkeleri-Ziraat Bankası Adana Şubesi Örneği.” Çukurova Araştırmaları Dergisi 2/2 (2016): 115-129.

Sözen, Metin ve Mete Tapan. 50 Yılın Türk Mimarisi. İstanbul: Türkiye İş Bankası Kültür Yayınları, 1973.

Şentürk, Şennur, Cengiz Can ve Paolo Girardelli. "Yaşayan Çizgiler”: Sant'Antonio Kilisesi Mimari Sergisi/“Segni essenziali”: Disegni Architettonici Della Chiesa di Sant'Antonio. İstanbul: Yap1 Kredi Yayınları, 1996.

Tanyeli, Uğur. Mimarliğın Aktörleri Türkiye 1900-2000. İstanbul: Garanti Galeri, 2007.

T.C. Kültür ve Turizm Bakanlığı Eskişehir Kültür Varlıklarını Koruma Bölge Kurulu Müdürlüğü Arşivi.

T.C. Ziraat Bankası Arşivi.

Tekeli, İlhan. “Türkiye'de Mimarlığın Gelişiminin Toplumsal Bağlamı,” Modern Türk Mimarlı̆̆ 1900-1980. Ed. Renata Holod, Ahmet Evin ve Süha Özkan. Ankara: TMMOB Mimarlar Odası Yayınları, 2007, 15-36.

Ünsal, Behçet. “İsmet Barutçu ve Nizamettin Doğu'dan Anılar.” Arkitekt 2 (330) (1968): 92-93.

Yaldız, Esra ve Özge Parlak. "Birinci Ulusal Mimarlık Dönemi Kamu Yapıları.” International Social Sciences Studies Journal 4/24 (2018): 4930-4947.

Yavuz, Yıldırım ve Süha Özkan. “Osmanlı Mimarlığının Son Y1lları.” Tanzimattan Cumhuriyete Türkiye Ansiklopedisi. 4. İstanbul: İletişim Yayınları, 1985, 1078-1085.

Yavuz, Y1ldırım. Imparatorluktan Cumhuriyete Mimar Kemalettin, 1870-1927. Ankara: TMMOB Mimarlar Odası ve Vakıflar Genel Müdürlüğü Ortak Yayını, 2009.

Yavuz, Yıldırım. “Ankara Çankaya' daki Birinci Cumhurbaşkanlığı Köşkü.” Tarih İçinde Ankara II Aralık 1998 Seminer Bildirileri. Ankara: ODTÜ Mimarlık Fakültesi Yayınları 2001, 341-412.

Yavuz, Yıldırım, “1923-1940 Arası Ankara' da Mimari,” Ankara Ankara. Ed. Enis Batur. İstanbul: Yap1 Kredi Yayınlar1, 1994, 201-208.

Yavuz, Yıldırım, Mimar Kemalettin ve Birinci Ulusal Mimarlık Dönemi. Ankara: ODTÜ Mimarlık Fakültesi Basım İşliği, 1981.

\section{Internet Kaynakları}

ICOMOS. “ICOMOS Türkiye Mimari Mirası Koruma Bildirgesi 2013.” Erişim 18 Nisan 2018. http://www.icomos.org.tr/Dosyalar/ICOMOSTR_tr0784192001542192602.pdf

Mimdap. “Osmanlı Bankası Şube Binaları.” Erişim 16 Ekim 2019. http://mimdap.org/?p=211241 


\section{KISALTMALAR}

BOA.: Başbakanlık Osmanlı Arşivi

EKVKBKM.: T.C. Kültür ve Turizm Bakanlığı Eskişehir Kültür Varlıklarını Koruma Bölge Kurulu Müdürlüğü

ETBA.: Eskişehir Tepebaşı Belediyesi Arşivi

ZBA.: Ziraat Bankası Arşivi 